\title{
Solar Ponds
}

T. S. Jayadev

Michael Edesess
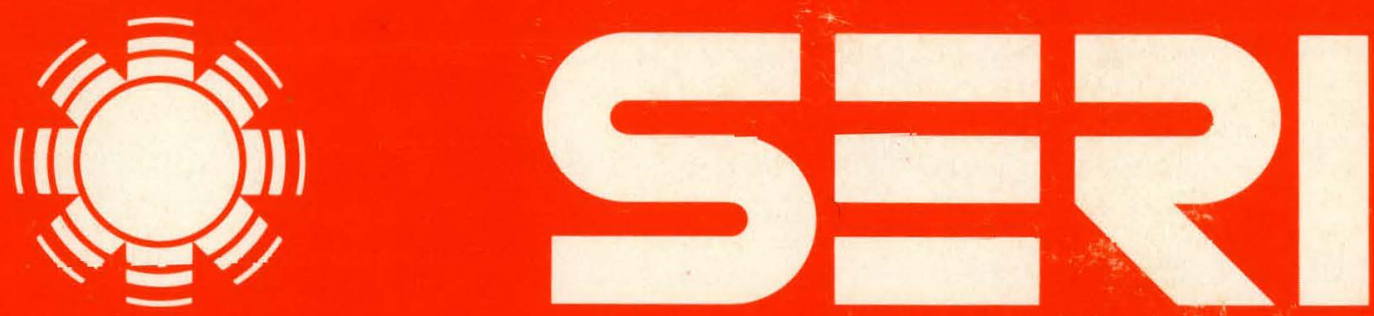

\section{Solar Energy Research Institute}

A División of Midwest Research Institute

1617 Cole Boulevard

Golden, Colorado 80401

Operated for the

U.S. Department of Energy

under Contract No. EG-77-C-01-4042

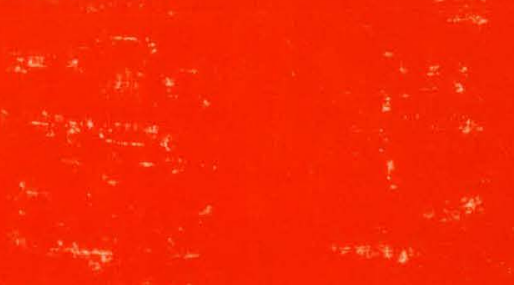




\section{DISCLAIMER}

This report was prepared as an account of work sponsored by an agency of the United States Government. Neither the United States Government nor any agency Thereof, nor any of their employees, makes any warranty, express or implied, or assumes any legal liability or responsibility for the accuracy, completeness, or usefulness of any information, apparatus, product, or process disclosed, or represents that its use would not infringe privately owned rights. Reference herein to any specific commercial product, process, or service by trade name, trademark, manufacturer, or otherwise does not necessarily constitute or imply its endorsement, recommendation, or favoring by the United States Government or any agency thereof. The views and opinions of authors expressed herein do not necessarily state or reflect those of the United States Government or any agency thereof. 


\section{DISCLAIMER}

Portions of this document may be illegible in electronic image products. Images are produced from the best available original document. 


\author{
Printed in the United States of America \\ Available from: \\ National Technical Information Service \\ UT.S. Department of Commerce \\ 5285 Port Royal Road \\ Springfield, VA 22161 \\ Price: \\ Microfiche $\$ 3.00$ \\ Printed Copy $\$ 4.50$
}

\begin{abstract}
NOTICE
This report was prepared as an account of work sponsored by the United States Government. Neither the United States nor the United States Department of Energy, nor any of their employees, nor any of their contractors, subcontractors, or their employees, makes any warranty, express or implied, or assumes any legal liability or responsibility for the accuracy, completeness or usefulness of any information, apparatus, product or process disclosed, or represents that its use would not infringe privately owned rights.
\end{abstract}


SERI /TR-731-587

UC CATEGORY: UC-59

SOLAR PONDS

T. S. JAYADEV

M. EDESESS

APRIL 1980

PREPARED UNDER TASK NO. 3525.12

Solar Energy Reșẹarch Institute

1536 Cole Boulevard

Golden, Colorado 80401

A Division of Midwest Research Institute

Prepared for the

U.S. Department of Energy

Contract No. EG: $77 \cdot \mathrm{C} \cdot 01 \cdot 4042$ 
THIS PAGE

\section{WAS INTENTIONALLY \\ LEFT BLANK}


$\hat{i}_{-\infty}^{a}$

This report is a compendium of analytic work on solar ponds performed at SERI during the past year. The work investigates the performance, economics, applications, and total quad potential of the various types of solar ponds, particularly the nonconvecting salt gradient pond. The overall finding is that solar ponds are a viable and economic technology with the potential for diplacing very significant quantities of conventional energy. Work was performed under the Systems Analysis and Testing Program, a major program element in the Systems Development Division, Office of Solar Applications.

\section{$\frac{\text { T.S. Tayader by M.E. }}{\text { T. S. Jayadev, Leader }}$ Solar Ponds Subtask}

Approved for

SOLAR ENERGY RESEARCH INSTITUTE
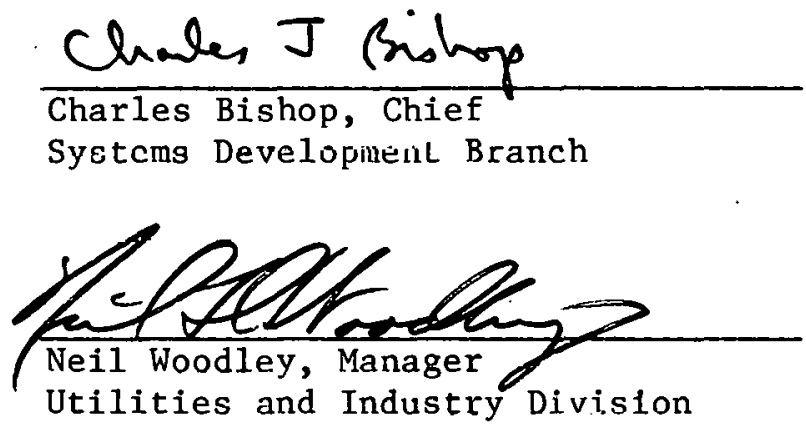


\section{THIS PAGE \\ WAS INTENTIONALLY \\ LEFT BLANK}


${ }^{10}\left(0^{-5}\right)$

\section{SUMMARY}

Solar ponds are probably the simplest and least expensive technology for conversion of solar energy to thermal energy. The solar pond is unique in its ability to act both as collector and storage. The cost of a solar pond per unit area is considerably less than that of any active collector available today. A combination of their economic and technical factors makes solar ponds attractive for district heating and industrial process heat applications. Solar ponds have the potential to displace significant quantities of fossil fuel in low-temperature heating applications in nonurban areas.

This report first describes the different types of solar ponds, including the nonconvecting salt gradient pond and various saltless pond designs. It then discusses the availability and cost of salts for salt gradient ponds, and compares the economics of salty and saltless ponds as a function of salt cost. A simple computational model is developed to approximate solar pond performance. This model is later used to size solar. ponds for district heating and industrial process heat applications. For district heating, ponds are sized to provide space conditioning for a group of homes, in different regions of the United States. Size requirement is on the order of one acre for a group of 25 to 50 homes. An economic analysis is performed of solar ponds used in two industrial process heat applications. The analysis finds that solar ponds are competitive when conventional heat sources are priced at $\$ 5$ per million Btu and expected to rise in price at a rate of $10 \%$ per year. The application of solar ponds to the generation of electricity is also discussed. Total solar pond potential for displacing conventional energy sources is estimated in the range of from one to six quadrillion Btu per year in the near and intermediate future. 
THIS PAGE

WAS INTENTIONALLY

LEFT BLANK 
TABLE OF CONTENTS

Page

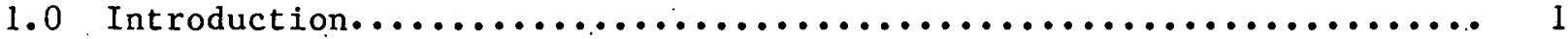

2.0 Types of Solar Ponds.............................. 1

2.1 Nonconvecting Ponds.............................. 1

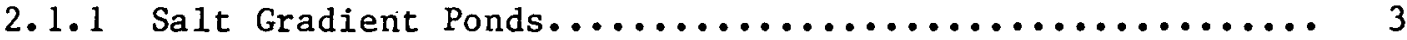

2.1.2 0ther Nonconvecting Ponds...................... 4

2.2 Convecting Ponds............................... 4

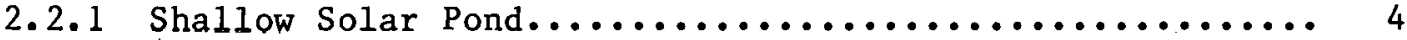

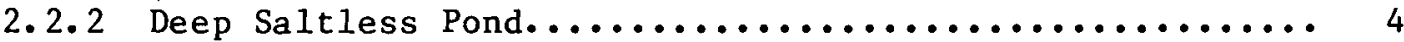

2.3. Collector-Pond Storage Combinations.................. 7

3.0 Solar Pond Costs and Performance...................... 7

3.1 Low-Cost Salts for Salt Gradient Solar Ponds............... 7

3.2 Comparison of Salt Gradient and Saltless Ponds...............12

3.2.1 Performance Comparison......................... 12

3.2.2 Economic Comparison............................ 13

3.3 Simplified Solar Pond Performance Model.................. 15

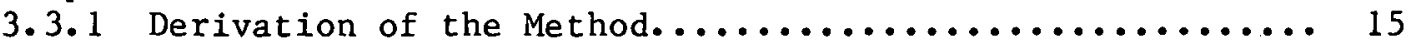

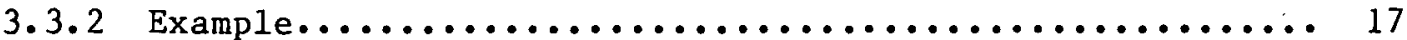

3.3.3 Application to Estimating the Area Required

for a Salt Gradient Pond.................... 17

4.0 Solar Pond Applications............................... 20

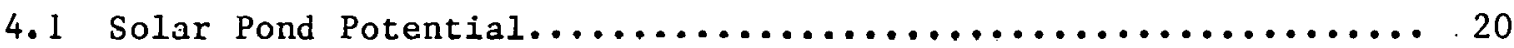

4.2 District Heating Applications....................... 24

4.3 Industrial Process Heat Applications.................... 24

4.4 Electric Power Generation.......................... 29

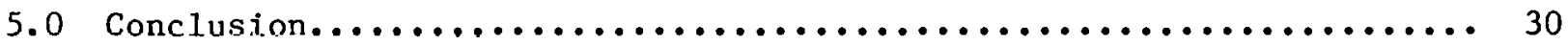

6.0 Acknowledgements................................. 31

7.0 References....................................... 31 
tii

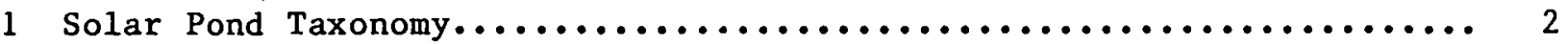

2 Salt Gradient Solar Pond................................ 3

3 Shallow Solar Pond Design............................. 5

4 Example of Deep Saltless Pond Design....................... 6

5 Solubility of Candidate Salts for Solar Ponds.................. 9

6 Major Salt Deposits U.S. and Canada....................... 11

7 Annual Temperature Profiles for Salty and Saltless Solar Ponds

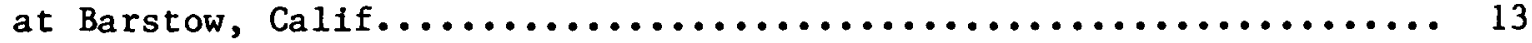

8 Example of a Rate-of-Return Calculation for (a) A Metal Can Washing Process and (b) A Commercial Laundry Process............. 30 


\section{LIST OF TABLES}

Page

1 Properties of Candidate Salts............................. 10

2 Estimated Costs for Salty and Saltless Ponds................... 14

3 Projected Pond Temperatures Obtained Using Developed Formulas....... 18

4 Base Case Salt Gradient Pond Assumptions..................... 19

5 Reflector Loss Adjustment Factors........................ 21

6 Quad Potential of Solar Ponds in the U.S.................... 22

7 Quad Potential of Solar Ponds by Application, Non-Metropolitan Areas Only............................ 23

8 Quad Potential of Solar Ponds by Application, Non-Metropolitan and Metropolitan Areas Outside Cities........... 25

9 Required Solar Pond Surface Areas and Depths at Various Locations in the United States.................................. 26

10 Comparative Cost and Performance of Conventional Solar Systems Versus a Solar Pond System............................. 28 


\subsection{INTRODUCTION}

The solar pond is probably the simplest technique for direct thermal conversion of solar energy. It is simultaneously a collector of solar radiation and a large body of thermal storage. Any pond converts insolation to heat, but most natural ponds quickly lose that heat through vertical convection within the pond and evaporation and convection at the surface. The solar pond artificially prevents either vertical convection, or surface evaporation and convection, or both. Because of its massive thermal storage and of measures taken to retard heat loss, the typical pond takes weeks for a $10^{\circ} \mathrm{C}$ temperature loss, even in the absence of insolation. Thus, the solar pond converts an intermittent energy source--solar radiation--into a reliable source of thermal energy.

Solar ponds can be operated at virtually all habitable latitudes. In some locations their surfaces may freeze in winter, but storage temperatures will remain high enough for low-temperature applications, and some insolation will still penetrate the ice. Solar ponds are less expensive per unit collector area and per unit of thermal output than flat-plate collectors, and they are more efficient at high temperatures. Their chief disadvantage compared with flat-plate collectors is that (with the possible exception of the shallow solar pond) they cannot be mounted on roof tops; therefore the area requirement for solar ponds is a concern. They would have little or no applicability in urban areas. Nevertheless, as Section 4.1 will show, they have the potential to displace a very significant amount of present day fossil fuel usage.

\subsection{TYPES OF SOLAR PONDS}

Most low-temperature solar thermal systems have collector and storage units as separate components. Storage is usually sufficient to last only a few days. With solar ponds, it is difficult to distinguish the collector unit from the storage unit: the same body of water serves as solar collector and storage medium. This body of water is usually large enough to provide long-term storage spanning seasons.

Solar pond concepts may be classified in two categories: (a) those that reduce heat loss by preventing convection within the water storage medium, and (b) those that reduce heat loss by covering the pond's surface. Combinations are of course possible, but one method is usually the primary determinant of the pond design.

2.1 NONCONVECTING PONDS - Nonconvecting ponds prevent heat loss by inhibiting thernal buoyancy convection. In most naturally occurring ponds, insolation is converted to heat within the pond and at its bottom; however, warmed water tends to rise to the surface, releasing its heat to the atmosphere. Nonconvecting ponds employ means to prevent the warmed waters from rising to the surface. 


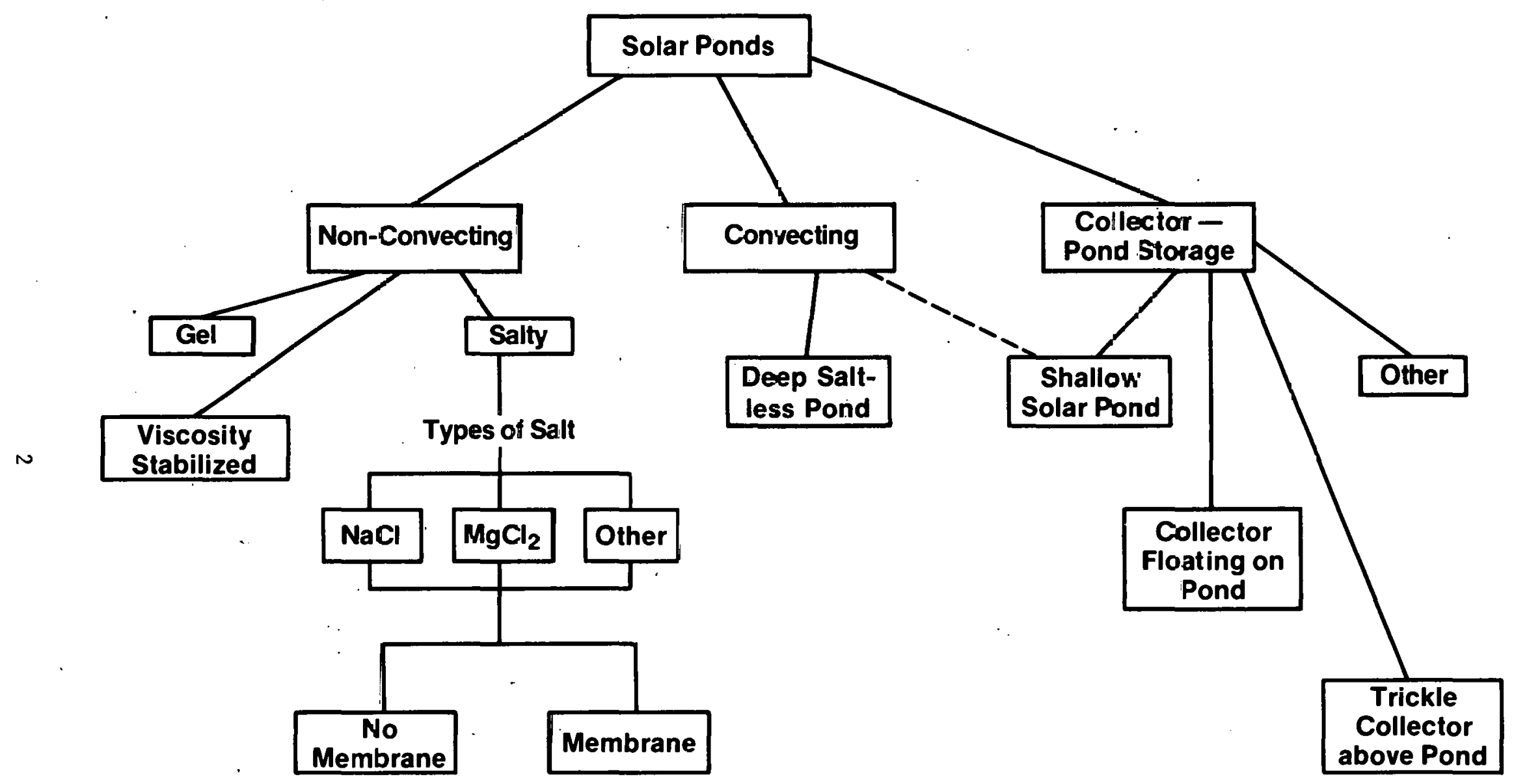

Figure 1. Solar Pond Taxonomy 
$\stackrel{i=-j}{i=j}$

2.1.1 SALT GRADIENT PONDS - Most studied of the solar ponds is the nonconvecting, salt gradient pond (Tabor, 1963, 1965 and 1980; Nielsen, 1979; Rab1, 1975; Zangrando, 197.8).

The salt gradient pond is a pond in which salt has been dissolved, in high concentrations near the bottom, and decreasing to low concentrations near the surface. Salts most commonly used are $\mathrm{NaCl}$ and $\mathrm{MgCl}_{2}$, although there are numerous other possibilities (see Section 3.1).

Solar radiation enters the pond, and whatever is not absorbed in the water on the way down is absorbed on the dark bottom (which may be an artificially blackened liner). As a result of this heat collection at the bottom, the deeper waters become warm.

Higher concentrations of salt prevail in the lower pond regions than in the upper regions, so the warmer, deep waters contain a higher density of dissolved salt than the colder waters near the surface. Pure water, when warmed, becomes less dense. If there were no salt concentration gradient in the pond there would be continuous convection of the warmed water from the bottom of the pond to the cooler layers near the top. However, the increased density created by the salt prevents this thermal buoyancy convection. Heat transfer to the surface of the pond occurs primarily by conduction, which is slow enough to enable the lower regions of the pond to maintain a high temperature $\left(100^{\circ} \mathrm{C}\right.$ has been measured in actual ponds).

In practice, the salt gradient pond has three layers, as shown in Figure 2. In the top layer vertical convection takes place due to the effects of wind and evaporation. This layer serves no useful purpose and is kept as thin as practically possible. The next layer, which may be approximately 1-m thick, contains an increasing concentration of salt with increasing depth and is nonconvecting. The bottom layer is a convecting layer which provides most of the thermal storage and facilitates heat extraction.

Variants on the simplest salt gradient pond design have been proposed to aid in controlling the boundaries of these layers. The so-called "membrane pond" (Rabl, 1975) contains a horizontal partition to separate the lower convecting zone from the middle nonconvecting zone and, possibly, a second partition slightly below the surface of the pond to minimize the surface convecting layer.

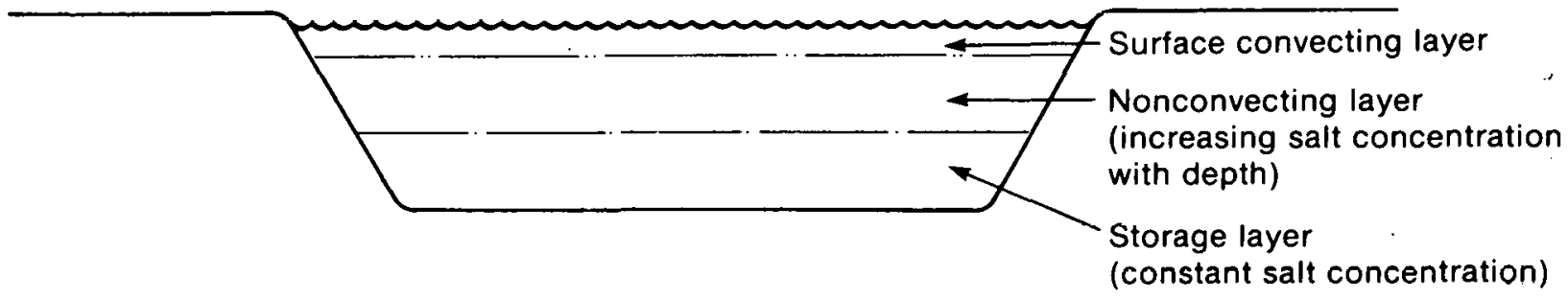

Figure 2. Salt Gradient Solar Pond 
Salt gradient ponds have been built and operated in such diverse locations as Israel (Sargent, 1979) and Canada (Saulnier, 1975) and in Ohio (Nielsen, 1979) and New Mexico (Zangrando, 1978) in the United States.

2.1.2 OTHER NONCONVECTING PONDS - Proposed alternatives to the salt gradient pond in the nonconvecting pond category are the viscosity stabilized pond (Battelle, 1975) and the gel pond. Both of them retard internal convec. tion by decreased fluidity of the water in the pond and have not yet advanced significantly beyond the conceptual stage.

\subsection{CONVECTING PONDS}

2.2.1 SHALLOW SOLAR POND - The single we11-researched example of the convecting pond is the shallow solar puld proposed and designed by Lawrence Livermore Laboratories (Dickinson, 1976; Casamajor, 1979). The shallow solar pond (see Figure 3) is about a $10-\mathrm{cm}$ depth of pure water enclosed in a large water bag (typically $5 \mathrm{~m}$ by $60 \mathrm{~m}$ ) with a blackened bottom, insulated below with foam insulation and on top with glazings. The water from many such ponds is pumped into a large storage tank for night storage and back into the water bags each morning, in an operating method called the "batch" mode. The shallow solar pond may also be operated in the "flow through" mode, in which the water flows continuously through the water bags in such a way as to maintain control over the outlet temperature.

Especially when operated in the flow-through mode, the shallow solar pond is almost the same as a flat-plate collector with water storage, the ma1n difference being that the solar pond collector is fixed in a horizontal position and is 1 ess costly than the usual flat-plate collectir. For thls reasou Figure 1 classiftes the shallow solar pond in the collector-pond storage category described below.

2.2.2 DEEP SALTLESS POND - Although the shallow convecting pond develops high-temperature water in a fairly short time, it requires pipes and plumbing to shuttle water out of the "ponds" each evening and storage tanks to hold the water at night. It also requires insulation under the water bags because the ground is allowed to cool off each night after the water is removed from the bags.

A more economical approach is to leave the water in the pond at night and to provide as much extra insulation as possible on top of the pond. During the daytime, when insolation must be received through the top of the pond, there is a limit as to how much top insulation can be used, and double glazing similar to that used in the shallow solar pond would be employed. But at night or during periods of low insolation additional insulation could be provided. An obvious and simple method would be to lay extra insulation over the top of the pond, either automatically or manually, whenever insolation falls below a prescribed level. 


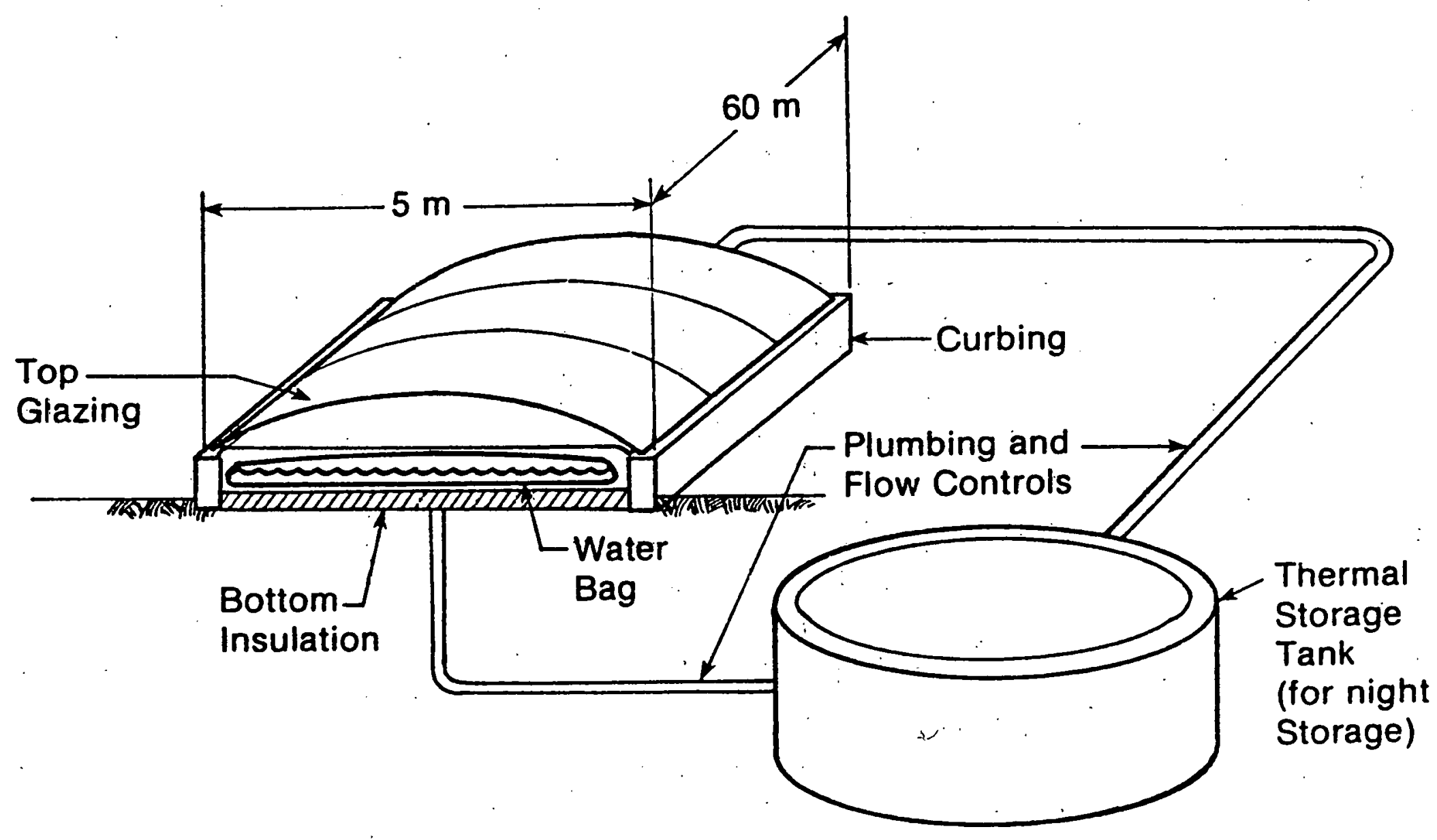

Figure 3. Shallow Solar Pond Design 
A more interesting and economical possibility is to spray foam insulation between the glazings and between glazing and pond when insolation drops below the prescribed level (Figure 4). A spray foam has been used successfully to provide night insulation for greenhouses (Groh, 1977). It has been found in practice to reduce the heat loss by at least $50 \%$, although in theory an $85 \%$ reduction should be attainable. It should be noted that the spray foam used in greenhouse experiments is a material normally used for firefighting. It seems likely that improvements could be made in the maleital for purpooco of pond insulation.

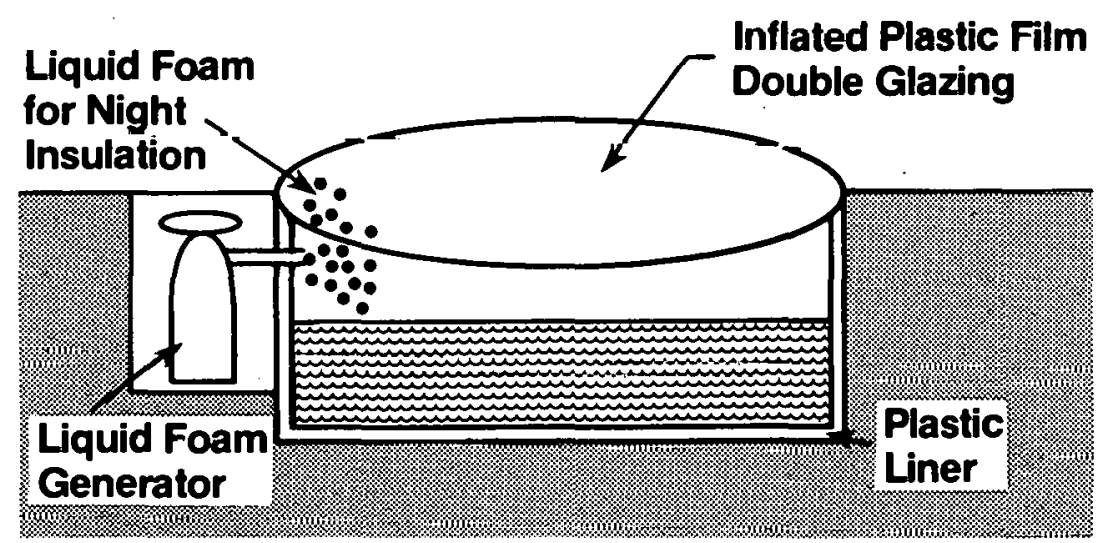

Figure 4. Example of Deep Saltless Pond Design

In the morning, the spray foam insulation would be allowed to settle and run off, leaving a negligible residue. The capital, cost of using spray foam to provide supplemental night insulation is estimated at less than $\$ 1 / \mathrm{m}^{2}$ of pond.

Besides eliminating the need for pipes, pumps, and plumbing to transport the water to nighttime storage, this "stationary" pond would not require bottom insulation. After a warmup period, the temperature of the ground would approach that of the pond wacer, providing good insulation. The only additional insulation that might be desired would be along the sides of the pond to prevent edge lusses.

To provide sufficient storage to even out daily and seasonal temperature fluctuations, the stationary convecting pond would be a deep pond, not a sha1.1.nw one.

The deep saltless pond concept was proposed hy Taylor (1977). There has been much less research as yet on the deep saltless pond than on the salt gradient pond. In Section 3.2, these two pond types will be compared as to projected costs and performance. 
2.3 COLLECTOR-POND STORAGE COMBINATIONS - Several collector-storage combinations have been suggested in which the thermal storage is provided by a large pond embedded in the ground.

In a Swedish design (Margen, 1978) a bank of tilted collectors is floated on a raft of insulation on top of a large pond. The heated water is drained into the pond and the collectors are fed with cooler water pumped back up from the pond.

A pond tested at the University of Virginia (Beard, 1978) had a trickle collector mounted just above the surface of a square pond. Between the pond surface and the collector was a layer of foam insulation "beads" through which the heated water trickled into the pond.

An Italian proposal (Cavalleri, 1977) calls for focusing collectors to heat water to a high temperature and deposit it in a pond of several square kilometers surface area. According to the proposal, this water can then be transported long distances in underground pipes to heat a city.

When the shallow solar pond concept is compared with the collector-pond storage designs, it is apparent that the shallow pond is analogous to the collector, and the night storage tank is analogous to the thermal storage.

\subsection{SOLAR POND COSTS AND PERFORMANCE}

For the salt gradient pond and the deep saltless pond--that is, essentially, for those solar ponds that are not collector/pond storage combinations--the chief costs are for earth moving, bottom liner, and for salt in the case of the salt gradient pond or for surface glazings and additional insulation in the case of the deep saltless pond. The costs of salt for the salt gradient pond may vary very widely. Therefore the relative attractiveness of salt gradient or saltless pond is primarily a function of the highly sitedependent salt cost.

3.1 LOW-COST SALIS FOR SALT GRADIENT SOLAR PONDS - The costs of salts for a solar pond represent a sizable fraction of the total initial investment. Depending upon the design details and the proximity to a source of salt, a typical $\mathrm{NaCl}$ salt pond may require $30 \%$ to $60 \%$ of the initial investment for the initial charge of $\mathrm{NaCl}$ (Apte, 1978; Battelle, 1975). Therefore, the identification of suitable, low-cost alternative salts could strongly affect the overall economic favorability of a salt pond.

A suitable salt must meet several criteria:

- it must be adequately soluble (with a solubility that increases with temperature);

- its solution must be adequately transparent to solar radiation;

- it must be widely available, so that its transportation costs do not offset the advantages of Its low purchase costs; and

- it must be environmentally benign. 
The amount of salt required and its necessary solubility and optical characteristics cannot be established theoretically because the understanding of stability in a stratified pond is not very well developed (Leshuk, 1978). However, certain sufficient conditions for pond stability can be inferred by analogy with successful $\mathrm{NaCl}$ ponds, and the overall thermal performance of a salty pond can be simulated by computer modeling when the solubility and optical properties of the alternative salt are known.

A typical $\mathrm{NaCl}$ pond has a solution concentration ranging from nearly zero at the surface to a maximum of 17 weight percent in the stgrage layer. This corresponds to a density gradient of only about $0.05 \mathrm{~g} \mathrm{~cm}^{-3}$ per meter depth. An alternative salt having a similar or lower diffusivity and which can provide a similar density gradient at operating temperatures should also produce a stable stratification. Figure 5 shows the solubility of some candidate salts. In all cases, the diffusivitles of the alternative salts are lower than that of $\mathrm{NaCl}$ and the temperature dependence of solubility is greater. Therefore, 3 a concentration sufficient to produce a density gradient of $0.05 \mathrm{~g} \mathrm{~cm}^{-3}$ per meter depth in a typical operating temperature gradient $\left(=20^{\circ} \mathrm{C} \mathrm{m}^{-1}\right)$ should provide as great or greater pond stability as would the $\mathrm{NaCl}$ salt.

Table 1 summarizes some properties of the candidate salts. Costs are on1y approximate since they vary substantially with location and time because of transportation costs; however, it is clear that only those salts that can be obtained as "waste" products offer substantial economic advantage. The magnesium chloride "bitterns" are available from plants that refine $\mathrm{NaCl}$, and these sites are numerous (Figure 6). Sodium sulfate, however, has the potential for much more widespread availability in the next few years as a waste product from flue gas desulfurization at coal-fired power plants.

Enforcement of existing EPA air quality standards will require all new coal-fired power plants and most gas- and oil-fired power plants that will be converted to coal (as required by the Nattonal Energy Act) to have sume flile. gas desulfurization. Several different desulfurization processes are under development by industry and evaluation by EPRI (Rush, 1978); two of the most promising use $\mathrm{Na}_{2} \mathrm{CO}_{3}$ and/or $\mathrm{NaHCO}_{3}$ and produce $\mathrm{Na}_{2} \mathrm{SO}_{4}$ as a flue gas desulfurization (FGD) waste product. These processes are being developed by joint ventures of Joy Industrial Equlpment Company with Niro Atomizer Company (Felsvang, 1978) and Wheelabrator-Frye, Inc., with Rockwell International (Escourt, 1978).

The quantities of FGD waste produced by a plant are enormous. A typlcal $500-\mathrm{MW}_{\mathrm{e}}$ plant (burning $\sim 0.2 \%$ sulfur cual) would producc appruximate $1 \mathrm{y} 250$ tone of FGD waste per day. Hundreds of oil- and gas-fired power plants around the country are potential future sites for production of the FGD waste. In the southwestern United States alone the capacity of such candidate plants is greater than $76 \mathrm{GW}_{e}$, and these plants are widely dispersed around the countryside with about $50 \%$ in rural areas near potential solar pond siles. Thus FCD waste salt may meet cost and availability criteria in the future.

Preliminary measurements at the Solar Energy Research Institute (SERI) indicate that the FGD waste salt's optical properties may also be acceptable, although, because of impurities, the FGD salt solutions are not as transparent 


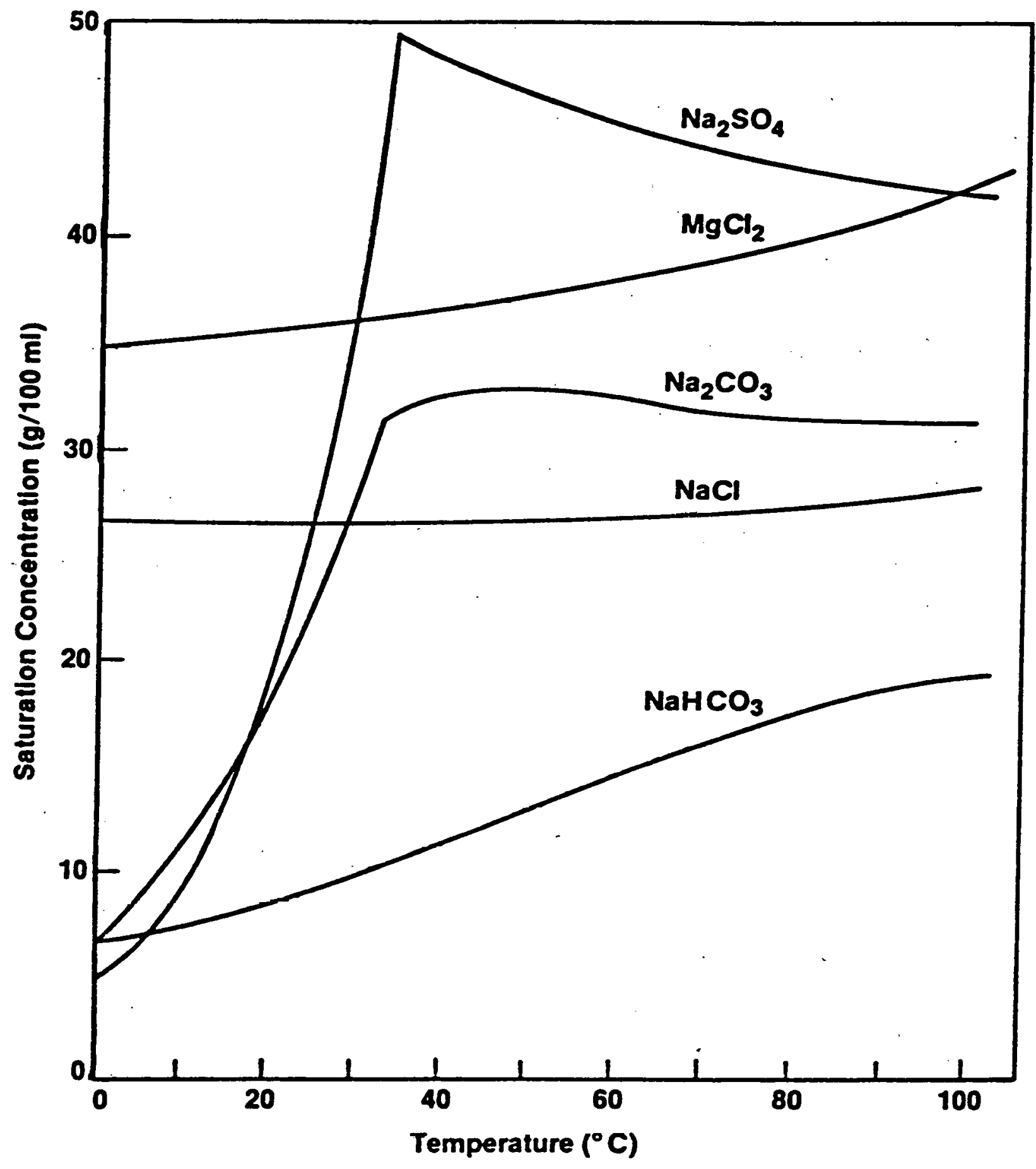

Figure 5. Solubility of Candidate Salts for Solar Ponds (LInke, 1965) 
Table 1. PROPERTIES OF CANDIDATE SALTS

\begin{tabular}{|c|c|c|c|c|}
\hline Sält & Formula & Source & $\begin{array}{c}\text { Costt } \\
\left(\$ / 10^{3} \mathrm{~kg}\right)\end{array}$ & Comments \\
\hline $\begin{array}{l}\text { Sodium } \\
\text { shlnride. }\end{array}$ & $\mathrm{NaCl}$ & (see Fig. 2) & 20 & \\
\hline \multirow[t]{3}{*}{$\begin{array}{l}\text { Sodium } \\
\text { carbonate }\end{array}$} & $\mathrm{Na}_{2} \mathrm{CO}_{3} \cdot \mathrm{H}_{2} \mathrm{O}$ & $\begin{array}{c}\text { Jynthotio } \\
\text { (Solvay Process) }\end{array}$ & 96 & East coast price \\
\hline & & $\begin{array}{c}\text { as Trona } \\
\text { (Green River, Wy.) }\end{array}$ & 61 & Wyoming price \\
\hline & & $\begin{array}{c}\text { as Trona } \\
\text { (Green River, Wy.) }\end{array}$ & 70 & California price \\
\hline $\begin{array}{l}\text { Sodium } \\
\text { bicarbonate }\end{array}$ & $\mathrm{NaHCO}_{3}$ & $\begin{array}{c}\text { Nahcolite } \\
\text { (Piceance Creek } \\
\text { Basin, Wy.) }\end{array}$ & $(\mathrm{f} 35)^{*}$ & $\begin{array}{c}\text { Byproduct of oil } \\
\text { shale mining } \\
\text { (not yet in pro- } \\
\text { duction) }\end{array}$ \\
\hline \multirow{3}{*}{$\begin{array}{l}\text { Sodium } \\
\text { sulf ate }\end{array}$} & $\mathrm{Na}_{2} \mathrm{SO}_{4}$ & "salt cake" & 47 & East coast price \\
\hline & & "salt cake" & 45 & West coast price \\
\hline & & $\begin{array}{l}\text { as Flue Gas } \\
\text { Desulfurleuliui waste }\end{array}$ & $(f 0) *$ & $\begin{array}{l}\text { Price dejeinds on } \\
\text { proximity of } \\
\text { other markets }\end{array}$ \\
\hline \multirow[t]{2}{*}{$\begin{array}{l}\text { Magnesium } \\
\text { chloride }\end{array}$} & $\mathrm{MgCl}_{2}$ & $\begin{array}{l}\text { salt plants } \\
\text { (sec Fig. 2) }\end{array}$ & 140 & $\begin{array}{l}99 \% \text { pure, hydra- } \\
\text { ted salt }\end{array}$ \\
\hline & & $\begin{array}{l}\text { as bitterng } \\
\text { (see Fig. 2) }\end{array}$ & $(\mathrm{f} 2)^{*}$ & $\begin{array}{l}\text { Waste product } \\
\text { also containing } \\
\text { otlıei salts (not } \\
\text { normally sold). }\end{array}$ \\
\hline
\end{tabular}

*Estimated prices 


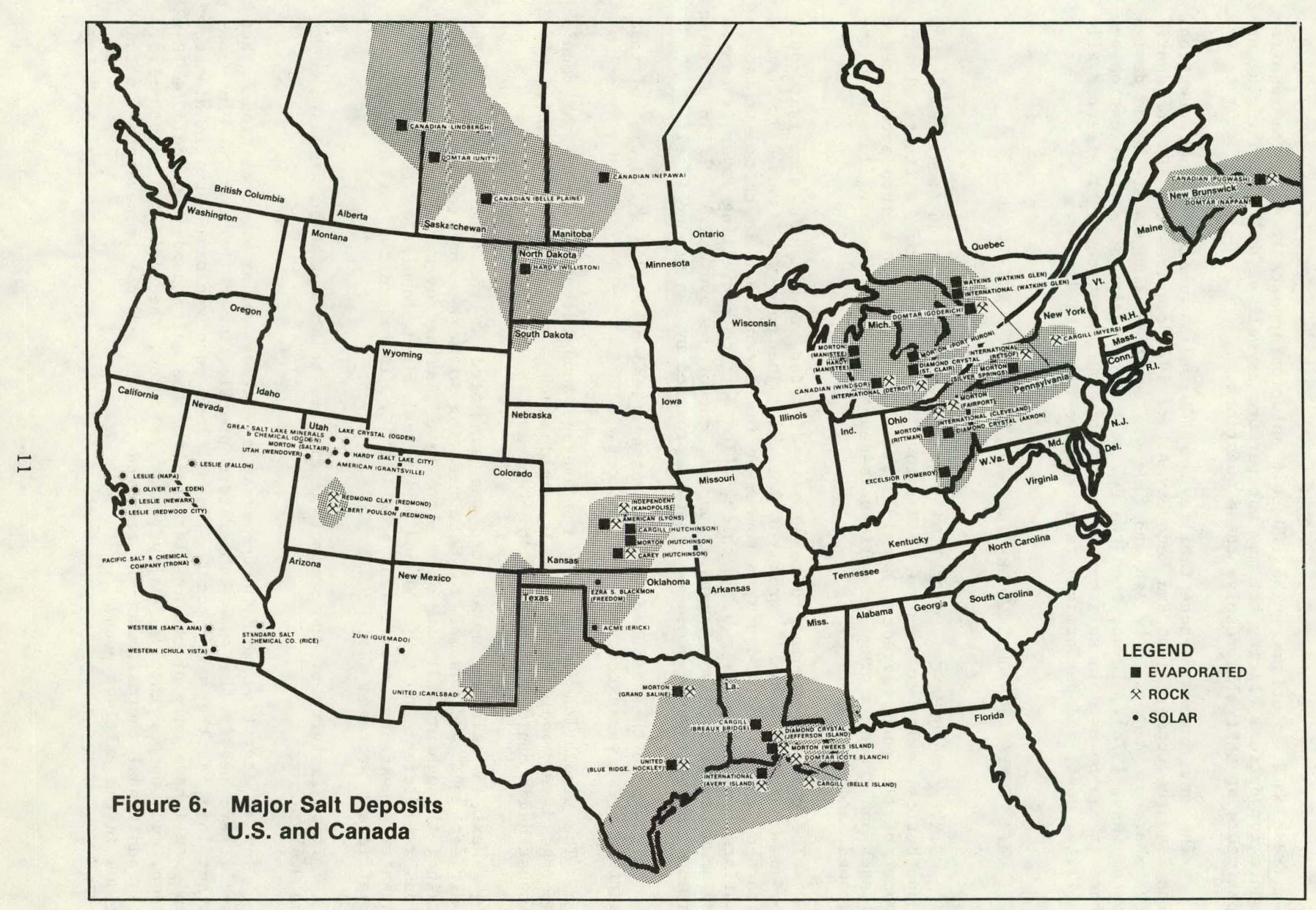


as fresh NaCl solutions. The FGD salt solution appears to meet the requirements for optical clarity but may not perform as well as NaCl. Continuing experiments at SERI will resolve these questions.

The environmental acceptability of FGD salts remains a moot question. The Resource Conservation and Recovery Act of 1976 requires the EPA to identify hazardous wastes. F1y ash and flue gas scrubber sludges may be so designated (Ray, 1978). If so, then the FGD salt may require some purification before it can be used in solar ponds. How this purification might affect availability, cost, and performance remains to be determined.

\section{3.? COMPARISON OF SALT GRADIENT AND SALTLESS PONDS}

3.2.1 PERFORMANCE COMPARISON - A computer simulation was run of a hypothetical salty solar pond at Barstow, Calif. Employing a finite element model of the pond (Jayadev, May 1979), the simulation took into account edge losses and ground storage as well as losses through the surface, losses to the ground, and pond storage.

The pond was assumed to be $30 \mathrm{~m}$ in diameter, roughly the size that could be used to heat a small group of houses. The pond was assumed to have a storage layer $1 \mathrm{~m}$ in depth, a nonconvecting layer $1.5 \mathrm{~m}$ in thickness, and a surface convecting layer $0.3 \mathrm{~m}$ thick. (The surface convecting layer is caused by wind turbulence and evaporation and cannot be avoided.) No insulation around the pond was assumed except that provided by the ground itself.

It was further assumed that a constant load of $35,343 \mathrm{~W}\left(50 \mathrm{~W} / \mathrm{m}^{2}\right.$ of pond surface area) was extracted from the pond.

The simulation showed that the average annual temperalure of the pond's storage layer would be $61^{\circ} \mathrm{C}$. It would reach a maximum of $81^{\circ} \mathrm{C}$ about midAugust and a minimum of $41^{\circ} \mathrm{C}$ in Mid-February.

Next, a saltless solar pond was simulated at the same location. The saltless pond was assumed to be convecting with the same temperature maintained throughout. It was assumed to have glazings over the top with a heat loss coefficient of $3 \mathrm{~W} / \mathrm{m}^{2}{ }^{\circ} \mathrm{C}$ and additional night insulation resulting in a nighttime heat loss coefficient of $1 \mathrm{~W} / \mathrm{m}^{2}{ }^{\circ} \mathrm{C}$. Therefure the surface heat loss coefficient averaged about $2 \mathrm{~W} / \mathrm{m}^{2}{ }^{\circ} \mathrm{C}$.

Transmissivily of the surface glazing to solar radiation was assumed to be 0.65 .

By an iterative modeling process, a saltless solar pond was found that would have nearly the same temperature profile, under the same $50 \mathrm{~W} / \mathrm{m}^{2}$ constant load, as the salty pond. The saltless pond would be $30 \mathrm{~m}$ in diameter and would have only ground insulation--like the salty pond--but would be 10-m deep, much deeper than the salty pond. As noted, the additional depth--i.e., the additional thermal mass--is required to even out the temperature fluctuations in the saltless pond. 
A computer simulation run on the saltless pond showed that its average temperature would be $60^{\circ} \mathrm{C}$. Its maximum temperature, reached in August, would be $80^{\circ} \mathrm{C}$ and its minimum temperature, in mid-February, would be $40^{\circ} \mathrm{C}$. Thus its temperature profile throughout the year would be much like that of the salty pond.

Figure 7 shows the temperature profiles of the two ponds.

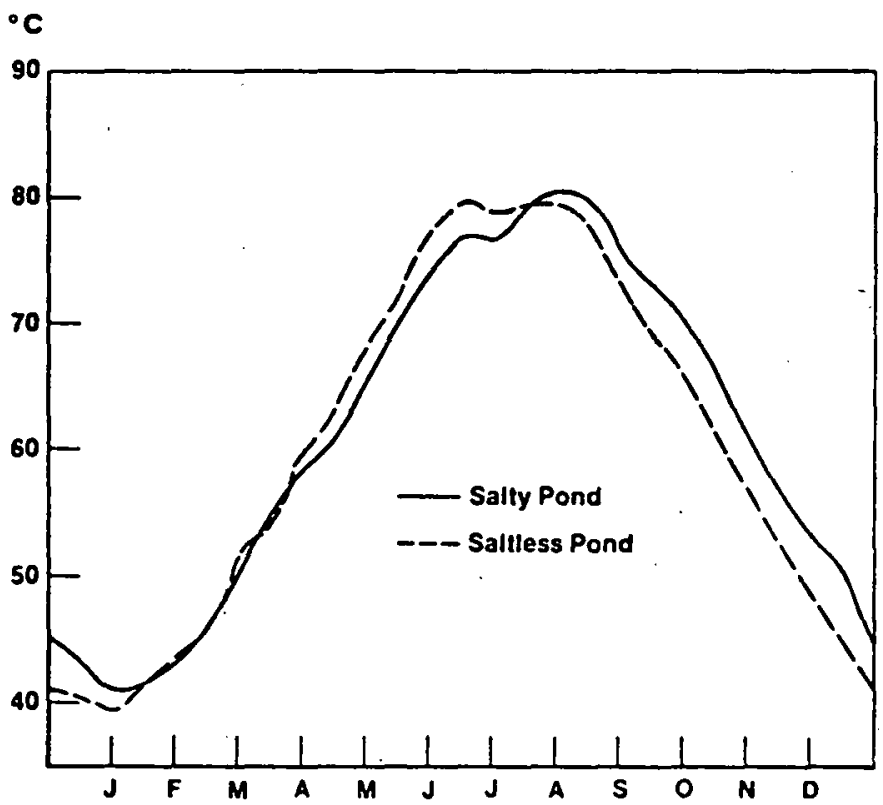

Figure 7. Annual Temperature Profiles for Salty and Saltless Solar Ponds at Barstow, Calif.

3.2.2 ECONOMIC COMPARISON - At the present stage of their development, solar pond costs can be only roughly estimated. These estimates will serve, however, to suggest economic comparisons between the salty and saltless ponds.

Capital expenses for the salty solar pond include excavation expense, the cost of a blackened liner for the bottom of the pond, and the cost of the salt.

The salty pond is $30 \mathrm{~m}$ in diameter and $2.8 \mathrm{~m}$ deep, so that at an excavation cost of $\$ 2 / \mathrm{m}^{3}$, the total excavation cost would be $\$ 4,000$, or about $\$ 5.60 / \mathrm{m}^{2}$ of pond surface area. The liner for the bottom of the pond must be a durable material like Hypalon, at a cost of $\$ 10 / \mathrm{m}^{2}$ or about $\$ 8,000$ for the. entire pond (including sides).

The salty pond used in the simulations would require about 0.5 ton of salt per square meter of pond surface area. The cost of salt varies widely 
with proximity to the supply and may be treated as a variable in economic comparisons with the saltless pond.

Capital expenses for the saltless solar pond include excavation expense, the cost of the liner, the cost of the surface structure and glazings, and the cost for night insulation.

The saltless pond that yielded approximately the same output as the salty pond was $10-\mathrm{m}$ deep. At a cost of $\$ 2 / \mathrm{m}^{3}$ the excavation expense is about $\$ 14,000$, or $\$ 20 / \mathrm{m}^{2}$ of pond surface area-- $\$ 14.40 / \mathrm{m}^{2}$ more than the salty pond. However, the cost of the liner could be reduced to about $\$ 2 / \mathrm{m}^{2}$ due to the much reduced requirement for retardation of leakage. For the entire pond, the liner cost would be about $\$ 1,600$.

The rnst of the surface structure and glazings depends upon the means of implementation. One possible scheme is to have a lattice structure that would be placed over the top of the pond. To this structure would be fastened sections of double-layered plastic film glazing, inflated by air at low pressure. For this design a conservative cost of $\$ 10 / \mathrm{m}^{2}$ is assumed.

If liquid foam insulation were used for night insulation, it could be sprayed into the space between the inflated plastic glazings. The cost of the liquid foam generating equipment averages less than $\$ 1 / \mathrm{m}^{2}$.

Table 2 summarizes rough costs for the salty and the saltless pond.

At a salt cost of $\$ 16.40 / \mathrm{m}^{2}$ pond surface area the cost for the salty pond equals that of the saltless pond. Since 0.5 ton of sall is required for each square meter of pond surface area, the break-even price for salt 1 s $\$ 32.80$ per ton. At a cost of salt lower than this, the salty pond is more economical. At a cost of salt higher than this, the saltless pond is more economical. For the $\$ 33.30 / \mathrm{m}^{2}$ cost of the saltless pond, the capital cost for energy at the 50 $\mathrm{W} / \mathrm{m}^{2}$ extraction rate is $\$ 666 / \mathrm{kW}_{\text {thermal }}$.

Table 2. ESTMMATED COSTS FOR SALTY AND SALTLESS PONDS

\begin{tabular}{|c|c|c|c|c|}
\hline \multirow[b]{2}{*}{ Pund Cúnipoulient } & \multicolumn{2}{|c|}{$\begin{array}{c}\text { Salty Pond } \\
\left(1250 \mathrm{~m}^{2} \times 2.8 \mathrm{~m}\right)\end{array}$} & \multicolumn{2}{|c|}{$\begin{array}{c}\text { Saltless Pond } \\
\left(1250 \mathrm{~m}^{2} \times 10 \mathrm{~m}\right)\end{array}$} \\
\hline & $\begin{array}{c}\text { Total Cost } \\
(\$)\end{array}$ & $\begin{array}{c}\text { Cost } / \mathrm{m}^{2} \\
\left(\$ / \mathrm{m}^{2}\right)\end{array}$ & $\begin{array}{c}\text { Total Cost } \\
(\$)\end{array}$ & $\begin{array}{c}\text { Cost } / \mathrm{m}^{2} \\
\left(\$ / \mathrm{m}^{2}\right)\end{array}$ \\
\hline Excavation & 4,000 & 5.60 & 14,000 & 20.00 \\
\hline Liner & 8,000 & 11.30 & 1,600 & 2.30 \\
\hline Glazings & & & 7,000 & 10.00 \\
\hline Night Insulatioir & & . & 700 & 1.00 \\
\hline Salt & & $\mathbf{x}$ & & \\
\hline Total $/ \mathrm{m}^{2}$ & & $\overline{\$ 16.90}+x$ & & $\$ 33.30$ \\
\hline
\end{tabular}


There has been insufficient working experience with solar ponds to provide a good estimate of operation and maintenance costs. With the salty pond, there is a requirement for frequent maintenance to preserve the salt concentration gradient and to maintain water clarity. There is no reason to expect higher operation and maintenance costs with the saltless pond than with the salty pond. In fact, there is reason to expect these costs to be lower with the saltless pond since it is covered and has no salt gradient to maintain.

3.3 SIMPLIFIED SOLAR POND PERFORMANCE MODEL - A simple method that enables easy calculation of solar pond sizes and outputs has been developed (Edesess, 1979).

3.3.1 DERIVATION OF THE METHOD - Whatever their differences, the various solar pond designs have a very large body of thermal storage in common. It is assumed that this storage is so large that daily fluctuations in ambient temperature and insolation have a negligible effect on the temperature of storage and that only seasonal variations in the environment need be considered.

It is assumed also that the heat loss from storage is related linearly to the difference between the temperature of storage and the temperature of. the ambient air and to the difference between the temperature of storage and the temperature of the ground. This means there must be effective heat loss coefficients $U_{a}$ and $U_{g}$ such that the rate of heat loss is $U_{a}\left(T-T_{a}\right)$ $+\mathrm{U}_{g}\left(\mathrm{~T}-\mathrm{T}_{g}\right)$, where $\mathrm{T}_{\mathrm{a}}$ is the ambient temperature, $\mathrm{T}_{\mathrm{g}}$ is the ground temperature (presumably equal to $\overline{\mathrm{T}}_{\mathrm{g}}$, the average annual ambient temperature), and $\mathrm{T}$ is the temperature of the storage layer of the pond. In the saltless pond, $T$ is assumed to be the temperature at any point.

Suppose that characteristic heat loss coefficients $U_{s}$, $U_{e}$, and $U_{b}$ can be identified for a pond of surface area $A$, perimeter $P$, and depth $D$, where $U_{s}$ is the coefficient of heat loss from the surface of the pond (in $\mathrm{W} / \mathrm{m}^{2}{ }^{\circ} \mathrm{C}$ ), $U_{e}^{\mathrm{s}}$ is the coefficient of heat loss from the edges of the pond (in $W / m{ }^{\circ} \mathrm{C}$ ), $U_{b}$ is the coefficient of heat loss from the bottom of the pond (in $\mathrm{W} / \mathrm{m}^{2}{ }^{\circ} \mathrm{C}$ ), and $A$ is measured in square meters with $P$ and $D$ measured in meters. Then, the coefficients of heat loss to the ambient air $U_{a}$ and to the ground $U_{g}$, respectively, can be expressed in terms of $U_{s}, U_{e}, U_{b}, A$, and $P$ as follows: ${ }^{g}$

$$
\mathrm{U}_{\mathrm{a}}=\mathrm{AU}_{\mathrm{s}}+\mathrm{PU}_{\mathrm{e}} \text {, and } \mathrm{U}_{\mathrm{g}}=\mathrm{AU}_{\mathrm{b}} \text {. }
$$

It is a reasonable approximation to model the insolation and the ambient temperature as sine waves, and, for simplicity, it is also assumed that the load can be represented as a sine wave.

Thus, let 


$$
\begin{aligned}
T_{a}(t) & =\bar{T}_{a}+\tilde{T}_{a} \sin 2 \pi\left(t-\phi_{T}\right) \\
I(t) & =\bar{I}+\tilde{I} \sin 2 \pi\left(t-\phi_{I}\right) \\
L(t) & =\bar{L}+\tilde{L} \sin 2 \pi\left(t-\phi_{L}\right)
\end{aligned}
$$

The time $t$ and the phase angles $\phi_{T}, \phi_{I}, \phi_{L}$ are measured in years. If insolation peaks in June, then $\phi_{T}$ is approximately 0.22 ; if ambient temperature peaks about a month afterward, then $\phi_{\mathrm{T}}$ is approximately 0.30 .

Let A signify the solar collection area, $\bar{\tau} \bar{\alpha}$ the fraction of insolation transmitted to the storage area of the pond, and $\rho \mathrm{Vc}$ the total heat capacity of storage (where $\rho$ is the water density, $V$ is the bolume of storage, and $c_{p}$ is its heat capacity per unit mass).

An energy balance yields

$$
\bar{\tau} \overline{\alpha A I}(t)=L(t)+U_{a}\left[T(t)-T_{a}(t)\right]+U_{g}\left[T(t)-\bar{T}_{a}\right]+\rho V c_{p} \dot{T}(t)
$$

or

$$
\begin{aligned}
\dot{T}(t)+\frac{U_{a}+U_{g}}{\rho V c_{p}} T(t)=\frac{1}{\rho V c_{p}}[\bar{\tau} \bar{\alpha} \overline{\mathrm{I}} & +\left(U_{a}+U_{g}\right) \bar{T}_{a}-\overline{\mathrm{L}} \\
& +\bar{\tau} \overline{\alpha A} \tilde{\mathrm{I}} \sin 2 \pi\left(t-\phi_{I}\right) \\
& +\mathrm{U}_{\mathrm{a}} \ddot{\mathrm{T}}_{\mathrm{a}} \sin 2 \pi\left(t-\phi_{\mathrm{T}}\right) \\
& \left.-\tilde{\mathrm{L}} \sin 2 \pi\left(t-\phi_{L}\right)\right] .
\end{aligned}
$$

The solution to this differential equation is

$$
T(t)=T+\Psi(t)-C\left(t_{0}\right) e^{-\sigma t}
$$

where

$$
\begin{aligned}
\overline{\mathrm{T}} & =\overline{\mathrm{T}}_{\mathrm{a}}+\frac{\bar{\tau} \bar{\alpha} \mathrm{A} \overline{\mathrm{I}}-\overline{\mathrm{L}}}{\mathrm{U}_{\mathrm{a}}+\bar{U}_{\mathrm{g}}} \\
\Psi(t) & =\frac{\mathrm{S}}{\rho V c_{\mathrm{p}}}\left[\bar{\tau} \bar{\alpha} \mathrm{AI} h\left(t-\phi_{I}\right)+\mathrm{U}_{a_{\mathrm{T}}} \tilde{\mathrm{T}}_{\mathrm{a}} \mathrm{h}\left(\mathrm{t}-\phi_{\mathrm{T}}\right)-\tilde{\mathrm{L}} \mathrm{h}\left(\mathrm{t}-\phi_{\mathrm{L}}\right)\right] \\
h(t-\phi) & =[\sigma \sin 2 \pi(t-\phi)-2 \pi \cos 2 \pi(t-\phi)] /\left[(2 \pi)^{2}+\sigma^{2}\right]
\end{aligned}
$$




$$
\begin{aligned}
& \sigma \quad=s\left(U_{a}+U_{g}\right) / \rho V c_{p} \\
& c\left(t_{0}\right)=\bar{T}-\bar{T}_{a}+\psi\left(t_{o}\right) e^{\sigma t_{0},},
\end{aligned}
$$

and $t_{0}$ is the startup date for the pond (in years from January 1), at which time $i t$ is assumed $T=\bar{T}_{a} \cdot S$ is the number of seconds in a year if $I$ and $L$ are expressed in watts.

Note that Equation 1 expresses the pond storage temperature as the sum of the long-term average pond temperatupe $\bar{T}$, a periodic temperature deviation $\Psi(t)$, and a transient term $c\left(t_{0}\right) e^{\sigma t}$.

Setting the derivative of Equation 1 equal to zero, one finds that in the steady state, extreme temperatures occur at the times

$$
(1 / 2 \pi) \tan ^{-1}[\Psi(0.25) / \Psi(0)]
$$

By plugging these times into Equation 1 , one can find the maximum and minimum temperatures.

3.3.2 EXAMPLE - For a circular salty pond simulated by Nielsen (1979), of $12-\mathrm{m}$ radius and $2-\mathrm{m}$ depth, wall losses were $3573 \mathrm{~W}$ and floor losses were $2920 \mathrm{~W}$ when the pond temperature was $50^{\circ} \mathrm{C}$ and ambient temperature was $10^{\circ} \mathrm{C}$. (Note that only earth insulation was used in this simulation.) Assuming that the coefficient of heat loss to ambient is $\mathrm{U}_{\mathrm{a}}=3573 /\left(50^{\circ}-10^{\circ}\right)$ or $\mathrm{U}_{\mathrm{a}}=89.3$ $\mathrm{W} /{ }^{\circ} \mathrm{C}$, and the coefficient of heat loss to ground is $U_{g}=2920 /\left(50^{\circ}-10^{\circ}\right)=73$ $\mathrm{W} /{ }^{\circ} \mathrm{C}$, the projected pond temperatures shown in Table 3 are obtained with the formulas just developed. (The poind is assumed to have been started on April 1. Transmission through the nonconvective layer is assumed to be $25 \%$, ambient temperatures are $10 \pm 15^{\circ} \mathrm{C}$, and insolation is $200 \pm 50 \mathrm{~W} / \mathrm{m}^{2}$.)

\subsubsection{APPLICATION TO ESTIMATING THE AREA REQUIRED FOR A SALT GRADIENT} POND - The formulas developed in 3.3.1 can be applied to estimating the required size of a solar pond. For the simplest version of the solar pond sizing method, a "base-case" salt gradient pond with a surface convecting layer $0.3^{-m}$ thick and a nonconvecting layer $1.2-\mathrm{m}$ thick is assumed. These parameters are not necessarily optimal for every location and application, but they provide a conservative estimate of required pond size.

For the base-case salt gradient pond, an average optical transmission of 0.31 through the surface convecting and nonconvecting layers is assumed. Surface heat losses are assumed to be $0.4 \mathrm{~W} / \mathrm{m}^{2}{ }^{\circ} \mathrm{C}$; bottom losses, $0.1 \mathrm{~W} / \mathrm{m}^{2}{ }^{\circ} \mathrm{C}$ (differential between pond and ground temperatures); and edge losses, $2.2 \mathrm{~W} /{ }^{\circ} \mathrm{C}$ per meter of pond perimeter (this would be reduced substantially if the edges were insulated). These assumptions are summarized in Table 4. Note that heat loss coefificients and optical transmission vary with local conditions and pond 
Table 3. PROJECTED POND TEMPERATURES OBTAINED USING DEVELOPED FORMULAS

\begin{tabular}{|c|c|c|c|c|c|}
\hline \multirow[b]{2}{*}{ Year } & \multirow[b]{2}{*}{ Month } & \multicolumn{4}{|c|}{ Projected Temperatures } \\
\hline & & No Load & $\begin{array}{c}5 \mathrm{~kW} \\
\text { Constant } \\
\text { Load }\end{array}$ & $\begin{array}{c}5+3 \mathrm{~kW} \\
\text { Summer } \\
\text { Peaking }\end{array}$ & $\begin{array}{l}5+3 \mathrm{~kW} \\
\bar{W} \text { inter } \\
\text { Peaking }\end{array}$ \\
\hline & $\begin{array}{ll}\text { July } & 1 \\
\text { Oet. } & 1\end{array}$ & $\begin{array}{l}51.0 \\
\text { fif . }\end{array}$ & $\begin{array}{l}44.1 \\
56.7\end{array}$ & $\begin{array}{l}40.8 \\
53.7\end{array}$ & $\begin{array}{l}47.4 \\
59.7\end{array}$ \\
\hline & $\begin{array}{ll}\text { Jan. } 1 \\
\text { Apr. } 1 \\
\text { July } 1 \\
\text { Oct. } 1\end{array}$ & $\begin{array}{l}53.7 \\
49.8 \\
67.1 \\
72.8\end{array}$ & $\begin{array}{l}43.0 \\
38.7 \\
55.7 \\
61.4\end{array}$ & $\begin{array}{l}45.1 \\
41.2 \\
53.4 \\
58.7\end{array}$ & $\begin{array}{l}40.9 \\
38.1 \\
58.0 \\
64.0\end{array}$ \\
\hline - Year 2 & $\begin{array}{cc}\text { Jan. } 1 \\
\text { Apr. } 1 \\
\text { July } 1 \\
\text { Oct. } 1\end{array}$ & $\begin{array}{l}56.3 \\
50.9 \\
67.5 \\
73.0\end{array}$ & $\begin{array}{l}44.9 \\
39.4 \\
56.0 \\
61.5\end{array}$ & $\begin{array}{l}47.1 \\
42.0 \\
53.7 \\
58.9\end{array}$ & $\begin{array}{l}42.6 \\
36.8 \\
58.3 \\
64.1\end{array}$ \\
\hline & $\begin{array}{ll}\text { Jan. } 1 \\
\text { Apr. } 1\end{array}$ & $\begin{array}{l}56.4 \\
50.9\end{array}$ & $\begin{array}{l}44.9 \\
39.4\end{array}$ & $\begin{array}{l}47.2 \\
42.0\end{array}$ & $\begin{array}{l}42.7 \\
36.8\end{array}$ \\
\hline $\begin{array}{l}\text { Steady } \\
\text { State }\end{array}$ & $\begin{array}{l}\text { Aver age } \\
\text { Min imum } \\
\text { Maximum }\end{array}$ & $\begin{array}{l}62.0 \\
49.6 \\
74.4\end{array}$ & $\begin{array}{l}50.5 \\
38.1 \\
62.9\end{array}$ & $\begin{array}{l}50.5 \\
41.4 \\
59.6\end{array}$ & $\begin{array}{l}50.5 \\
34.8 \\
66.2\end{array}$ \\
\hline
\end{tabular}

construction. If better estimates of these parameters than those assumed for the base case can be obtained, the expanded methud described in Edeseso (1979) should be used. An explanation of the choice of transmission and heat loss coefficients for the base-case salt gradient pond is also contained there.

The required solar pond surface area is a function of desired annual average pond temperature, annual average ambient temperature, annual insolation, annual load, and latitude. The surface area increases as either the desired average pond temperature or the annual load increases, and the surface area decreases as the annual average ambient temperature or insolation increases: The latitude indicates only the average elevation angle of the sun and, therefore, the surface reflective losses, which are greater at higher latitudes. Hence, because of larger reflective losses and the likelihood of decreased ambient temperature and insolation, the required pond surface area tends to increase with increasing latitude. 
$i_{i=-j}^{=1}$

Table 4. BASE CASE SALT GRADIENT POND ASSUMPTIONS

\begin{tabular}{|c|c|c|}
\hline Parameter & Value & Comments \\
\hline $\begin{array}{l}\text { Surface convecting } \\
\text { layer thickness }\end{array}$ & $0.3 \mathrm{~m}$ & $\begin{array}{l}\text { Varies with surface con- } \\
\text { ditions }\end{array}$ \\
\hline $\begin{array}{l}\text { Nonconvecting layer } \\
\text { thickness }\end{array}$ & $1.2 \mathrm{~m}$ & May not be optimal \\
\hline $\begin{array}{l}\text { Average optical trans- } \\
\text { mission through top } \\
\text { two layers }\end{array}$ & 0.31 & $\begin{array}{l}\text { Should be lower at high } \\
\text { latitudes }\end{array}$ \\
\hline $\begin{array}{l}\text { Heat loss from pond } \\
\text { surface through non- } \\
\text { convecting layer }\end{array}$ & $0.4 \mathrm{~W} / \mathrm{m}^{2}{ }^{\circ} \mathrm{C}$ & \\
\hline Edge losses & $\begin{array}{l}2.2 \mathrm{~W} /{ }^{\circ} \mathrm{C} \text { per } \\
\text { meter of } \\
\text { perimeter }\end{array}$ & $\begin{array}{l}\text { Varies with soil content, } \\
\text { elevation of pond surface } \\
\text { above/below grade, and } \\
\text { presence of edge insula- } \\
\text { tion }\end{array}$ \\
\hline $\begin{array}{l}\text { Losses from pond } \\
\text { bottom to ground }\end{array}$ & $0.1 \mathrm{~W} / \mathrm{m}^{2}{ }^{\circ} \mathrm{C}$ & $\begin{array}{l}\text { Varies with soil content } \\
\text { and existence/depth of } \\
\text { ground water }\end{array}$ \\
\hline
\end{tabular}

Inputs required are:

$\overline{\mathrm{T}} \quad=$ annual average pond temperature desired in ${ }^{\circ} \mathrm{C}$ (if in ${ }^{\circ} \mathrm{F}$, subtract 32 and multiply by $5 / 9$ );

$\overline{\mathrm{T}}_{\mathrm{a}} \quad=$ annual average ambient temperature in ${ }^{\circ} \mathrm{C}$;

$\overline{\mathrm{I}} \quad=$ annual average insolation in $\mathrm{W} / \mathrm{m}^{2}$ (if in langleys per day, multiply by 0.4845$)$;

$\overline{\mathrm{L}}=$ annual average load in watts (if in Btu/yr, multiply by 3.34 $\times 10^{-5}$ ); and

$\phi \quad=$ latitude in degrees. 
(1)

Multiply the insolation $\overline{\mathrm{I}}$ by the adjustment factor $f$ to obtain $\overline{\mathrm{I}}_{r}$, the insolation received after adjustment for surface reflection losses. The factor $f$ is a function of latitude $\phi$, as shown in Table 5 .

Multiply $\overline{\mathrm{I}}_{r}$ by 0.31 to obtain $\overline{\mathrm{I}}_{\mathrm{p}}$, the insolation received in the pond after adjustment for reflection and transmission losses.

Let $T_{d}=\bar{T}-\bar{T}$. Then, the equation for the radius $r$ (in meters) of a circular pond to meet the requirements is:

$$
r=\frac{2.2 \mathrm{~T}_{\mathrm{d}}+\left|4.84 \mathrm{~T}_{\mathrm{d}}^{2}+\mathrm{L}\left(0.3183 \mathrm{I}_{\mu}-0.1592 \mathrm{~T} d\right)\right|^{1 / 2}}{\overline{\mathrm{I}}_{\mathrm{p}}-0.5 \mathrm{~T}_{\mathrm{d}}}
$$

Once the radius is determined, use $A=\pi r^{2}$ to find the required surface area in square meters. I'o obtain the required area in acres, multiply by 0.000247 .

Some specimen pond areas calculated using this method are given in Section 4.2.1. Pond depths and outputs may also be estimated using the formulas developed in Section 3.3.1. Methods for so doing are detailed in Edesess (1979).

\section{0 SOLAR POND APPLICATIONS}

Solar ponds are readily applicable to such low-temperature uses as residential or commercial heating and hot water, low-temperature industrial or agricultural process heat, or preheating for higher temperature industrial process heat (IPH) application. Combined with organic Rankine cycle engines or thermoelectric devices, solar ponds may be used for electric power generation. By using the heat to run an absorption chiller, solar ponds may be used for cooling.

4.1 SOLAR POND POTENTIAL - The potential of solar ponde for displaoing fossil fuels in the United States is gręat. To estimate potential market size, the approximate number of quads $\left(10^{15} \mathrm{Btu}\right)$ of energy used in each potential solar pond application was compiled in Table 6 . It was assumed that no market for solar ponds is possible within urban areas, but that nonmetropolitan areas (i.e., rural) have prime potential, and metropolitan areas outside cities (i.e., suburban) also have potential for solar pond penetration. Energy end use was assumed to be divided in proportion to the population among nonmetropolitan areas, metropolitan areas outside cities, and cities.

Table 7 shows the potential of solar ponds in nonmetropolitan areas alone at $15 \%, 30 \%$, and $100 \%$ penetration rates. At $15 \%$ penetration, solar ponds would provide $1-1 / 4$ quads, and at $30 \%$ penetration, they would provide $2-1 / 2$ quads. 
Table 5. REFLECTION LOSS ADJUSTMENT PACTORS

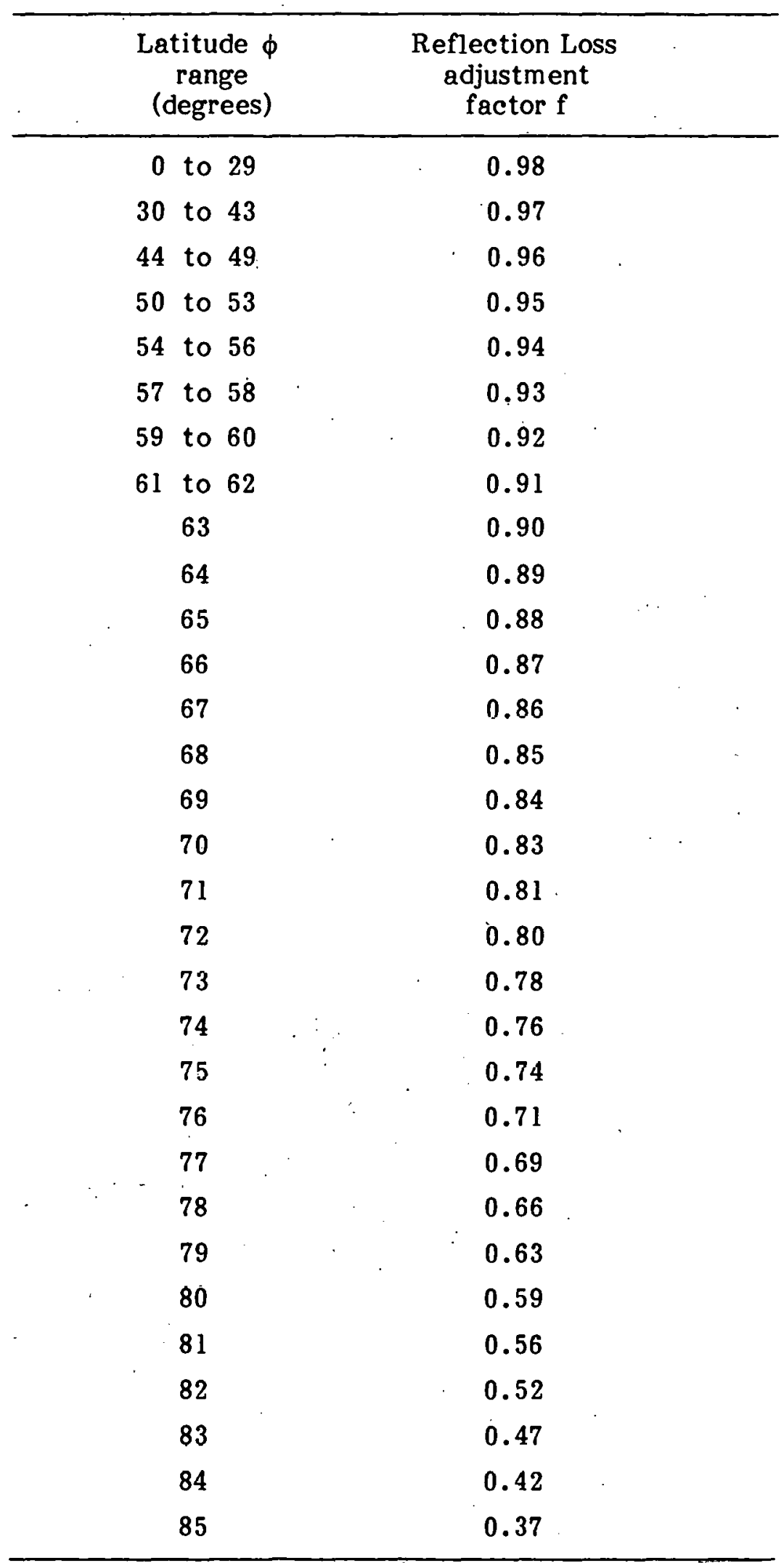


QUAD FOTENTIAL OF SOLAR PONDS IN THE U.S.

(80 Quad Total U.S. Energy Consumption Assumer)

\begin{tabular}{|c|c|c|c|c|c|c|}
\hline & & & Market S & & & \\
\hline & & & Region & & & \\
\hline & & Northeast: & $\begin{array}{l}\text { North } \\
\text { Central }\end{array}$ & Scut? & West & Total \\
\hline 1 & Aesidential: Mon-Metro & .52 & 1.39 & .82 & .44 & 3.17 \\
\hline Space & Resid.: Metro..,Outside City & 1.53 & 1.75 & .84 & .78 & 4.9 \\
\hline Heating & Commercial: Hon-Metro & .24 & .64 & .38 & .20 & 1.46 \\
\hline - & Commer.: Metro,Outside C1ty & .71 & .81 & .39 & .36 & 2.27 \\
\hline 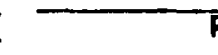 & Residential: hin-Vetro & .09 & .20 & .28 & .09 & .66 \\
\hline Water & Resid.: Metro. ,Outside City & .27 & .26 & .28 & .20 & 1.01 \\
\hline Heating & Commerc la 1: Non-Metro & .02 & .05 & .07 & .02 & .16 \\
\hline r & Commer.: Metro,Outside C1ty & .07 & .07 & .07 & .05 & .26 \\
\hline 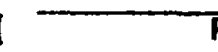 & Residentlal: Won-hetro & 0 & .08 & .2 & .06 & .34 \\
\hline Cooling & Res1d.: Metro,Outside C1ty & $\mathbf{0}$. & .12 & .2 & .14 & .46 \\
\hline$\checkmark$ & Commerclal: Non-Metro & 0 & .06 & .16 & .06 & .28 \\
\hline & Commer.: Metro,Outside City & .02 & .09 & .17 & .14 & .42 \\
\hline Industrial & Sow-Grade Hea: & .16 & .19 & Tद & .07 & .54 \\
\hline Process Hea & atre-Heat & 1.07 & 1.28 & .82 & .48 & 3.67 \\
\hline Agricul ture & Low-Grade Heat & -- & .1 & .1 &.$T$ & .3 \\
\hline Electricity & Irrigation & -- & .1 & .1 &. & .3 \\
\hline Clothes & Res.Idential: Non-Metro & .01 & .03 & .03 & .01 & .08 \\
\hline Drying & Resid.: Metro, Dutside City & .03 & .03 & .04 & .02 & .12 \\
\hline
\end{tabular}

Table 6. 
QUAD POTENTIAL OF SOLAR PONDS BY APPLICATION .

Non-Metropolitan Areas Only

\begin{tabular}{lccc} 
& \multicolumn{3}{c}{ Percentage of Penetration } \\
\hline & $15 \%$ & $30 \%$ & $100 \%$ \\
1. Residential & 0.64 & 1.28 & 4.25 \\
2. Commercial & 0.28 & .57 & 1.90 \\
3. Industrial & 0.23 & .47 & 1.57 \\
4. Agricultural & 0.09 & 0.18 & 0.6 \\
& & & 8.32
\end{tabular}

Table 7. 
Table 8 shows the potential of solar ponds in both nonmetropolitan areas and metropolitan areas outside cities. At 15\% penetration the potential is over three quads, and at $30 \%$ penetration it is more than six quads.

4.2 DISTRICT HEATING APPLICATIONS - To minimize heat losses at the pond edges, it is best to maximize the ratio of pond area to pond perimeter. Therefore a small pond will not be as efficient as a larger one. Thus, it is better for residentlal heating applications to build one large pond for a group of houses than to build a small pond for each house.

Table 9 shows the results of sizing the base-case salt gradient solar pond using the simple technlque described in Section 3.3, at various locations in the United States. The load is assumed to be $50 \mathrm{~kW}_{\mathrm{th}}$ on the average, attaining a maximum of $70 \mathrm{~kW}_{\mathrm{th}}$ during the peak demand period. Sizing calculations were performed for winter peaking and sumwes peaking loads. Summer. peaking loads are more likely at lower latitudes where solar ponds may be used for cooling. The surface area requirement is unaffected by the timing of the peak demand. The depth requirement is affected, however; greater depth is required for a winter peaking load. Sizing was performed both for a "hot pond" $\left(75^{\circ} \mathrm{C}\right.$ average $/ 50^{\circ} \mathrm{C}$ minimum) and a "warm pond" $\left(60^{\circ} \mathrm{C}\right.$ average $/ 40^{\circ} \mathrm{C}$ minimum) at each location.

The surface area requirement for the hot pond to serve the specified load ranges from about one-half acre in Miami, Fla., and Los Angeles, Calif., to a little over two acres in Boston, Mass. Surface area requirements for the warm pond range from a little over one-third of an acre in Miami and Los Angeles to almost one acre in Bosluil. The depth requirement ranges from $1.9 \mathrm{~m}$ for a summer peaking load in lilaml fui toth hot and warm ponds to $4.5 \mathrm{~m}$ for a winter peak.ing 1 nad and a warm pond in Denver. (Note that the depth requirement may be relaxed by increasing the surface area and thereby raising the cntire temprinture profile of the pond.)

The pond sized in each case, with allowance for different climates and consequent user loads, would be sufficient to serve roughly 25 to 50 households.

4.3 INDUSTRIAL RROCESS HEAT APPT.TCATIONS - To assess the feasibility of solar pond technology for IPH applications and compare the suitability of ponds with more conventional solar technology, two industrial applications as reported in the Snlar Energy Research Institute's (SERI) case studies (Brown, 1979; Hooker, forthcoming) were selected for allalysis.

One application focuses upon the hot water requirements for aluminum can washing in a Colorado manufacturing planl where cans are shaped and trimmed from shect $\varepsilon$ tock, then washed and dried before being sent for bottom coating and painting. On the average, the can processing lines operate $24 \mathrm{~h}$ per day, 6.5 days per week, and 50 weeks during the year. Most of the energy used in the plant (supplied by natural gas at $\$ 1.93 / \mathrm{GJ}$ ) is required for can drying. However, approximately $22 \%$ of the total energy input goes to a water heater that supplies $60^{\circ} \mathrm{C}\left(140^{\circ} \mathrm{F}\right)$ water to the can washer. Water is heated via steam. The total annual energy requirement for can washing on one process line is $2.3 \times 10^{12}$ joules (2185 MBtu). 


\section{QUAD POTENTIAL OF SOLAR PONDS BY APPLICATION}

Non-Metropolitan and Metropolitan Areas Outside Cities

Percentage of Penetration

\begin{tabular}{lllr}
\hline 1. RESIDENTIAL & $15 \%$ & $30 \%$ & $100 \%$ \\
2. COMMERCIAL & 1.61 & 3.22 & 10.74 \\
3. INDUSTRIAL & 0.73 & 1.46 & 4.85 \\
4. AgRICULTURAL & 0.63 & 1.26 & 4.21 \\
TOTAL & 0.09 & 0.18 & 0.6 \\
& 3.06 & 6.12 & 20.40
\end{tabular}

Table 8. 
Table 9. REQUIRED SOLAR POND SURFACE AREAS AND DEPTHS AT VARIOUS LOCATIONS IN THE UNTTED STATES

\begin{tabular}{|c|c|c|c|c|c|c|c|c|c|}
\hline \multirow[b]{3}{*}{ Region } & \multirow[b]{3}{*}{ Location } & \multirow{3}{*}{$\begin{array}{l}\text { Latitude } \\
()^{\circ}\end{array}$} & \multirow{3}{*}{$\begin{array}{c}\text { Insol:atjon } \\
\left(w / n^{2}\right) \\
\text { Avg. Min. }\end{array}$} & \multirow{3}{*}{$\begin{array}{c}\text { Ambient } \\
\text { Temp. ( }{ }^{\circ} \text { ) } \\
\text { Avg./Min. }\end{array}$} & \multirow{3}{*}{$\begin{array}{c}\text { Pond } \\
\text { Temp. }\left({ }^{\circ} \mathrm{C}\right) \\
\text { Avg./Min }\end{array}$} & \multicolumn{4}{|c|}{ Pond Sizes for $50 . \mathrm{kW}_{\text {th }}$ Avg. $/ 70 \mathrm{~kW}_{\text {th }}$ Max. Load $\overline{\mathrm{a}}$} \\
\hline & & & & & & \multicolumn{2}{|c|}{ Winter Peakirg } & \multicolumn{2}{|c|}{ Summer Peaking } \\
\hline & & & & & & Area (acres) & Irepth (m: & Area (acres) & Depth (m) \\
\hline Pacific & $\begin{array}{l}\text { Los Angeles } \\
\text { Los Angeles }\end{array}$ & $\begin{array}{l}34 \\
34\end{array}$ & $\begin{array}{l}209 / 112 \\
209 / 112\end{array}$ & $\begin{array}{l}16.5 / 12.5 \\
16.5 / 12.5\end{array}$ & $\begin{array}{l}75 / 50 \\
60 / 40\end{array}$ & $\begin{array}{l}0.52 \\
0.38\end{array}$ & $\begin{array}{l}3.5 \\
4.2\end{array}$ & $\begin{array}{l}0.52 \\
0.38\end{array}$ & $\begin{array}{l}2.6 \\
2.7\end{array}$ \\
\hline Mountain & $\begin{array}{l}\text { Denver } \\
\text { Denver }\end{array}$ & $\begin{array}{l}39 \\
39\end{array}$ & $\begin{array}{l}206 / 96 \\
206 / 96\end{array}$ & $\begin{array}{l}10.1 /-1.2 \\
10.1 /-1.2\end{array}$ & $\begin{array}{l}75 / 50 \\
60 / 40\end{array}$ & $\begin{array}{l}0.63 \\
0.44\end{array}$ & $\begin{array}{r}3.7 \\
.4 .5\end{array}$ & $\begin{array}{l}0.63 \\
0.44\end{array}$ & $\begin{array}{l}3.0 \\
3.3\end{array}$ \\
\hline West N. Central & $\begin{array}{l}\text { Omaha } \\
\text { Omaha }\end{array}$ & $\begin{array}{l}41 \\
41\end{array}$ & $\begin{array}{l}174, ; 57 \\
174 ; 67\end{array}$ & $\begin{array}{l}9.7 /-6.6 \\
9.7 /-6.6\end{array}$ & $\begin{array}{l}75 / 50 \\
60 / 40\end{array}$ & $\begin{array}{l}1.04 \\
0.64\end{array}$ & $\begin{array}{l}3.6 \\
443\end{array}$ & $\begin{array}{l}1.04 \\
0.64\end{array}$ & $\begin{array}{l}3.2 \\
3.4\end{array}$ \\
\hline West S. Central & $\begin{array}{l}\text { Callas } \\
\text { Liallas }\end{array}$ & $\begin{array}{l}33 \\
33\end{array}$ & $\begin{array}{l}193.103 \\
193 ! 103\end{array}$ & $\begin{array}{l}19.0 / 7.4 \\
19.0 / 7.4\end{array}$ & $\begin{array}{l}75 / 50 \\
60 / 40\end{array}$ & $\begin{array}{l}0.59 \\
0.42\end{array}$ & $\begin{array}{l}3.4 \\
4.2\end{array}$ & $\begin{array}{l}0.59 \\
0.42\end{array}$ & $\begin{array}{l}2.6 \\
2.8\end{array}$ \\
\hline East N. Central & $\begin{array}{l}\text { Chicrgo } \\
\text { Chicago }\end{array}$ & $\begin{array}{l}41 \\
41\end{array}$ & $\begin{array}{l}160 / 53 \\
160 / 53\end{array}$ & $\begin{array}{l}10.3 /-4.3 \\
10.3 /-4.3\end{array}$ & $\begin{array}{l}75 / 50 \\
60 / 40\end{array}$ & $\begin{array}{l}1.37 \\
0.76\end{array}$ & $\begin{array}{l}2.5 \\
\leq .2\end{array}$ & $\begin{array}{l}1.37 \\
0.76\end{array}$ & $\begin{array}{l}3.1 \\
3.4\end{array}$ \\
\hline East S. Central & $\begin{array}{l}\text { Jackson, MS } \\
\text { Jackson, ME }\end{array}$ & $\begin{array}{l}32 \\
32\end{array}$ & $\begin{array}{l}185 / 93 \\
185 / 93\end{array}$ & $\begin{array}{l}18.3 / 8.4 \\
18.3 / 8.4\end{array}$ & $\begin{array}{l}75 / 50 \\
60 / 40\end{array}$ & $\begin{array}{l}0.66 \\
0.45\end{array}$ & $\begin{array}{l}3.4 \\
4.1\end{array}$ & $\begin{array}{l}0.66 \\
0.45\end{array}$ & $\begin{array}{l}2.7 \\
3.3\end{array}$ \\
\hline New England & $\begin{array}{l}\text { Boston } \\
\text { Boston }\end{array}$ & $\begin{array}{l}42 \\
42\end{array}$ & $\begin{array}{r}145,53 \\
145,53\end{array}$ & $\begin{array}{l}10.7 /-1.6 \\
10.7 /-1.6\end{array}$ & $\begin{array}{l}75 / 50 \\
60 / 40\end{array}$ & $\begin{array}{l}2.07 \\
0.96\end{array}$ & $\begin{array}{l}3.2 \\
3.8\end{array}$ & $\begin{array}{l}2.07 \\
0.96\end{array}$ & $\begin{array}{l}2.9 \\
3.2\end{array}$ \\
\hline Middle Atlantic & $\begin{array}{l}\text { Philedelphia } \\
\text { Philedelphia }\end{array}$ & $\begin{array}{l}40 \\
40\end{array}$ & $\begin{array}{l}154.62 \\
154.62\end{array}$ & $\begin{array}{l}12.6 / 0.2 \\
12.6 / 0.2\end{array}$ & $\begin{array}{l}75 / 50 \\
60 / 40\end{array}$ & $\begin{array}{l}1.42 \\
0.77\end{array}$ & $\begin{array}{l}3.2 \\
3.9\end{array}$ & $\begin{array}{l}1.42 \\
0.77\end{array}$ & $\begin{array}{l}2.9 \\
3.1\end{array}$ \\
\hline South Atlantic & $\begin{array}{l}\text { Miarni } \\
\text { Miami }\end{array}$ & $\begin{array}{l}25 \\
25\end{array}$ & $\begin{array}{l}194 / 134 \\
194 / 134\end{array}$ & $\begin{array}{l}24.2 / 19.6 \\
24.2 / 19.6\end{array}$ & $\begin{array}{l}75 / 50 \\
60 / 40\end{array}$ & $\begin{array}{l}0.50 \\
0.37\end{array}$ & $\begin{array}{l}2.9 \\
3.6\end{array}$ & $\begin{array}{l}0.50 \\
0.37\end{array}$ & $\begin{array}{l}1.9 \\
1.9\end{array}$ \\
\hline
\end{tabular}

Approximately the demand of 95 to 50 households. 
The second application is for hot water used in washing in a large Colorado commercial laundry. Water is heated via steam and effluent heat exchangers. Steam is primarily used in the ironing machines (the largest load in the plant) so that it is conceivable that the required hot water at $82^{\circ} \mathrm{C}$ $\left(180^{\circ} \mathrm{F}\right)$ could be alternatively supplied directly by a solar system. The hot water load constitutes only $8 \%$ of the total plant energy demand. The laundry normally operates for one daytime shift, $8 \mathrm{~h}$ each day, 6 days per week. Total annual energy to be supplied is $4.3 \times 10^{12}$ joules ( $\left.4085 \mathrm{MBtu}\right)$. Energy is supplied via natural gas at $\$ 1.85 / G J$.

Solar pond systems were sized to assist the IPH needs of the metal can manufacturer and the commercial laundry. In theory, a pond could have been sized to provide $82^{\circ} \mathrm{C}$ continuous output, as required for the commercial laundry. The incremental surface area and depth required, however, to increase the pond's minimum output temperature from $80^{\circ} \mathrm{C}$ to $82^{\circ} \mathrm{C}$ is considerably greater than that required to increase it from $60^{\circ} \mathrm{C}$ to $62^{\circ} \mathrm{C}$. Therefore, there is likely to be an optimal size at which the marginal cost of increasing the pond's area is equal to the cost of backup energy. Hence, the optimal solar pond may use backup, even though it may be feasible to size a solar pond large enough to require no backup.

For the metal can washing application, a solar pond was sized to achieve an annual average temperature of $55^{\circ} \mathrm{C}$, with an annual high of $65^{\circ} \mathrm{C}$, and an annual low of $45^{\circ} \mathrm{C}$. It was assumed that a $5^{\circ} \mathrm{C}$ loss would be suffered in exchanging heat from the pond. Hence, at its peak temperature of $65^{\circ} \mathrm{C}$, the pond will just satisfy without backup the application's requirement for $60^{\circ} \mathrm{C}$ water. At all other times, it will require backup to boost the temperature. The pond is $5143 \mathrm{~m}^{2}(1.27$ acres) in surface area and $4.9-\mathrm{m}$ deep. The capital cost of the pond alone is $\$ 128,000$ if salt is free, $\$ 173,000$ if salt costs $\$ 10$ per ton, and $\$ 218,000$ if salt costs $\$ 20$ per ton. The costs of the heat exchanger and piping were conservatively assumed to be $\$ 8 / \mathrm{m}^{2}$ of pond surface area.

For the laundry application, a solar pond was sized to achieve an annual average temperature of $65^{\circ} \mathrm{C}$, with an annual high of $80^{\circ} \mathrm{C}$, and an annual low of $50^{\circ} \mathrm{C}$. This pond is $3552 \mathrm{~m}^{2}(0.88$ acre) in surface area and $3.2-\mathrm{m}$ deep. Its capital cost is $\$ 76,000$ with free salt, $\$ 94,000$ at a salt cost of $\$ 10 /$ ton, and $\$ 112,000$ at a salt cost of $\$ 20 /$ ton. Again, heat exchanger and piping costs were assumed to be $\$ 8 / \mathrm{m}^{2}$.

The simulation codes PROSYS and ECONMAT (Brown, 1979) were used in SERI case studies of the two applications to assess annual performance and costs of alternative "conventional" solar IPH systems. Approximately 20 different collectors were analyzed and the most cost effective collector and system were chosen for each application. Table 10 shows the cost and performance characteristics of each conventional solar system and of the comparable solar pond system for three assumed salt costs. The annual energy outputs of the solar ponds for the two applications were calculated using the method described in Section 3.3. Note that the configured systems will annually dellver different amounts of energy. A comparison is possible, therefore, only on the basis of annualized energy costs or projected rates of return. It is useful, however, to compare the relative amounts of capital investment required for unit annual energy delivery. The capital capacity cost of the conventional systems (total 
Table 10. COMPARATIVE COST AND PERTORMANCE OP CONVENTIONAL SOLAR BYSTEMS YERSUS A SOLAR POND SYSTEM

\begin{tabular}{|c|c|c|c|c|c|c|}
\hline \multicolumn{7}{|c|}{ Metal Can Washing } \\
\hline System Type & $\begin{array}{c}\text { A:ea } \\
\text { Lond Required }\end{array}$ & $\begin{array}{c}\text { Annual } \\
\text { Energy Delivered }\end{array}$ & $\begin{array}{c}\text { Collector } \\
\text { Subsystem Cost }\end{array}$ & $\begin{array}{c}\text { Balance } \\
\text { of } \\
\text { Plart }\end{array}$ & Capital Cost & $\begin{array}{l}\text { Estimated } \\
\text { Annual OMPI }\end{array}$ \\
\hline $\begin{array}{l}\text { Parabolic Trough Collector } \\
\text { Heat Exchange Sqstem }\end{array}$ & $\begin{array}{l}1275 \mathrm{~m}^{2} \\
\left(13,635 \mathrm{ft}^{2}\right)\end{array}$ & $\begin{array}{l}2.3 \times 10^{12} \mathrm{~J} \\
(2,200 \mathrm{MBtu})\end{array}$ & $\$ 193,000$ & $\$ 197,000$ & $\$ 390,000$ & $\$ 7,500$ \\
\hline $\begin{array}{l}\text { Salt Gradient Pond } \\
\text { af } \$ 20 / \text { Ton For Salt }\end{array}$ & $\begin{array}{l}5143 \mathrm{~m}^{2} \\
\left(55,339 \mathrm{ft}^{2}\right)\end{array}$ & $\begin{array}{l}5.6 \times 10^{12} \mathrm{~J} \\
(5,320 \mathrm{MBlu})\end{array}$ & $\$ 218,000$ & $\$ 196 \$ 500$ & $\$ 414,600$ & $\$ 8,000$ \\
\hline $\begin{array}{l}\text { Salt Gradient Pand } \\
\text { at } \$ 10 / \text { Ton For Salt }\end{array}$ & $\begin{array}{l}5143 \mathrm{~m}^{2} \\
\left(55,339 \mathrm{ft}^{2}\right)\end{array}$ & $\begin{array}{l}5.6 \times 10^{12} \mathrm{~J} \\
(5,320 \mathrm{MBtu})\end{array}$ & $\$ 173,000$ & $\$ 196,600$ & $\$ 369,600$ & $\$ 6,000$ \\
\hline $\begin{array}{l}\text { Salt Gradient Pond } \\
\text { at. 0/Ton For Sal1 }\end{array}$ & $\begin{array}{l}5143 \mathrm{~m}^{2} \\
\left(55,339 \mathrm{ft}^{2}\right)\end{array}$ & $\begin{array}{l}5.6 \times 10^{12} \mathrm{~J} \\
(5,320 \mathrm{MB}: \mathrm{u})\end{array}$ & $\$ 128,000$ & $\$ 196,60\}$ & $\$ 324,600$ & $\$ 4,000$ \\
\hline \multicolumn{7}{|c|}{ Laundry Hot Water } \\
\hline System Type & $\begin{array}{c}\text { A.rea } \\
\text { Required }\end{array}$ & $\begin{array}{c}\text { Annual } \\
\text { Energy Delivered }\end{array}$ & $\begin{array}{c}\text { Collector } \\
\text { Subsystem Cost }\end{array}$ & $\begin{array}{c}\text { Balence } \\
\text { of } \\
\text { Plent }\end{array}$ & $\begin{array}{c}\text { Total } \\
\text { Capital Cost }\end{array}$ & $\begin{array}{l}\text { Estimated } \\
\text { Annual OMPI }\end{array}$ \\
\hline $\begin{array}{l}\text { Parabolic Trough Collector, } \\
\text { Heat Exchange System }\end{array}$ & $\begin{array}{l}2087 \mathrm{~m}^{2} \\
\left(22,450 \mathrm{ft}^{2}\right)\end{array}$ & $\begin{array}{l}2.96 \times 10^{12} \mathrm{~J} \\
(3,750 \mathrm{MBtu})\end{array}$ & $\$ 313,000$ & $\$ 319,800$ & $\$ 632,800$ & $\$ 13,500$ \\
\hline $\begin{array}{l}\text { Salt Gradient Pond } \\
\text { at } \$ 20 / \text { Ton For Salt }\end{array}$ & $\begin{array}{l}355 \hat{\alpha} \mathrm{m}^{2} \\
\left(38,920 \mathrm{ft}^{2}\right)\end{array}$ & $\begin{array}{l}3.06 \times 10^{12} \mathrm{~J} \\
(2,907 \mathrm{MEtu})\end{array}$ & $\$ 112,000$ & $\$ 112,7 \mathrm{CO}$ & $\$ 224,700$ & $\$ 4,500$ \\
\hline $\begin{array}{l}\text { Salt Gradient Pond } \\
\text { at } \$ 10 / \text { Ton For Salt }\end{array}$ & $\begin{array}{l}3552 \mathrm{~m}^{2} \\
\left(38,220 \mathrm{ft}^{2}\right)\end{array}$ & $\begin{array}{l}3.06 \times 10^{12} \mathrm{~J} \\
(2,907 \mathrm{MEtu})\end{array}$ & $\$ 94,000$ & $\$ 11 \approx, 700$ & $\$ 206,700$ & $\$ 3,700$ \\
\hline $\begin{array}{l}\text { Salt Gradient Pond } \\
\text { at } \$ 0 / \text { Ton For Salt }\end{array}$ & $\begin{array}{l}3552 \mathrm{~m}^{2} \\
\left(38,220 \mathrm{ft}^{2}\right)\end{array}$ & $\begin{array}{l}3.06 \times 10^{12} \mathrm{~J} \\
(2,907 \mathrm{MBtu})\end{array}$ & $\$ 76,000$ & $\$ 11:, 700$ & $\$ 188,700$ & $\$ \mathbf{3 , 5 0 0}$ \\
\hline
\end{tabular}

Includes materials and labor for installation of auxiliary equipment items, such as heat exchangers, plus $60 \%$ of direct field costs for indirects, continger.cy, and fee. 
capital cost divided by annual energy delivered) is approximately $\$ 165$ per GJ/yr $(\$ 173 / \mathrm{MBtu} / \mathrm{yr})$. The capital capacity costs of solar pond IPH systems vary between $\$ 74$ per GJ/yr for expensive salt and $\$ 60$ per GJ/yr for free salt $(\$ 77 / \mathrm{MBtu} / \mathrm{yr}$ to $\$ 62 / \mathrm{MBtu} / \mathrm{yr})$. However, approximately twice as much land area is required for the pond as for the conventional trough collectors to deliver the same annual energy.

Installation of a retrofit solar IPH system (no storage is assumed for these systems and full conventional backup is available) is a "service" investment whose costs are offset by savings accrued from reduced fuel consumption. To compare the economic viability of the parabolic trough with the solar pond, a rate of return calculation was performed for each application using the method identified in Dickinson (1979).

Equity financing was assumed, with a 20-yr service life, 7-yr depreciation, $50 \%$ tax rate, and $20 \%$ investment tax credit. No salvage value was taken. Therefore, a multiplier may be determined for various rates of return and the levelized cost of solar energy plotted against rate of return. On the same graph, the levelized cost of the fuel displaced may be plotted for various discount rates. The rate of return from the given project is then found at the intersection of the two curves. Figure 8 shows the rate of return calculation for the metal can washing application and the calculation for the commercial laundry. Two levelized fuel prices are assumed in each case: (1) current quoted price of fuel with an $8 \%$ rate of escalation and (2). fuel price of $\$ 5.00 / \mathrm{GJ}$ ( $\$ 5.27 / \mathrm{MBtu}$ ) escalating at $10 \%$ per annum. An efficiency of conversion to delivered heat of $85 \%$ in metal can washing and $75 \%$ in the laundry is assumed.

As can be seen in the charts, installation of any sort of solar IPH system in either application does not offer adequate return on investment when compared to costs of natural gas and a fuel price escalation rate of $8 \%$. However, when compared to natural gas at $\$ 5.00 / G J$ escalating at $10 \%$, the solar pond systems usually provide a rate of return in excess of $15 \%$, which is generally sufficient to warrant commitment of funds in general service investments. The alternative conventional parabolic trough systems offer less than half of this rate for the same fuel price scendilu.: Hence, solar ponds justify serious consideration as economic alternatives for low-temperature IPH. In addition, it appears that the return from solar pond systems is not highly sensitive to salt cost.

4. 4 ELECTRIC POWER GENERATOR - In combination with organic Rankine cycle engines or thermoelectric devices, solar ponds may be used for the generation of electric power. Conversion efficiency is 1 ow--on the order of $1 \%$ to $2 \%$ from insolation to electric output--but costs are so low that solar pondelectric applications may be economical in many cases. Much work is being done in Israel on solar pond-organic Rankine cycle engine generation of electricity (Sargent, 1979). It has been proposed that thermoelectric devices in comparison with solar ponds would provide an even more cost-effective means of generating electricity (Jayadev, August 1979). It should be noted that solar pond-electric generation has a significant advantage over other solarelectric systems in that, because of the inherent solar pond storage, electricity is available on demand, rather than only intermittently. 

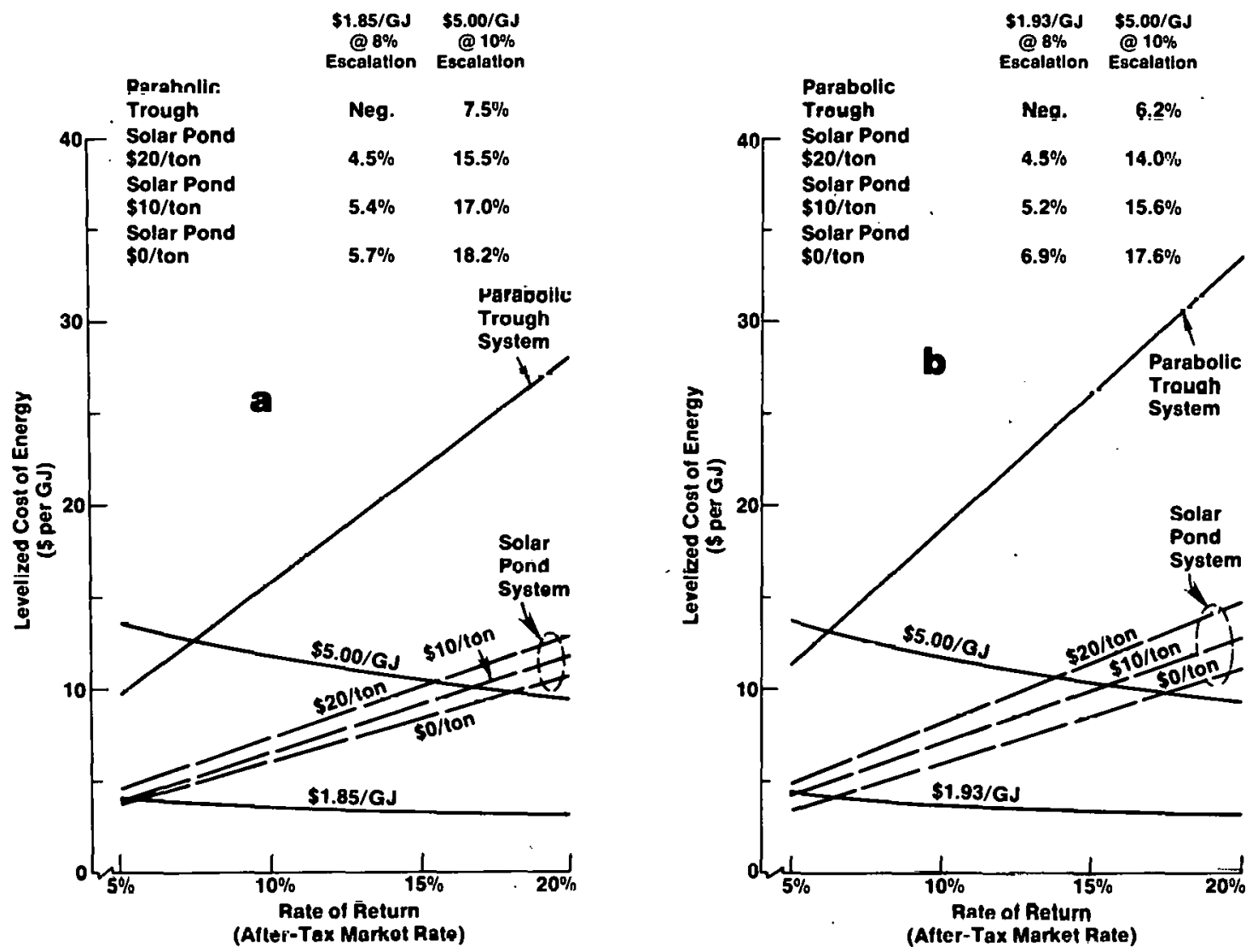

Figure 8. Example of a Rate-of-Return Calculation for

(a) A Metal Can Washing Process and

(b) A Commerclal Laundry Process

\subsection{CONCLUSION}

Solar ponds have considerable potential for economically providing district heating for residential and commercial areas, industrial process heat, and electric power. There has as yet, unfortunately, been little research, development, and demonstration of solar ponds in the United States, although there has been a major effort undertaken in Israel. Work is needed to research inexpensive salts for salt gradient ponds and surface glazings and night insulation for saltless ponds. An accumulation of experience with demonstration ponds and commercial ponds in the United States would provide needed lessons in design and maintenance techniques. With a little effort 
applied to their development, solar ponds are one of the most promising nearterm solar technologies.

\subsection{ACKNOWLEDGEMENTS}

Assistance provided by the following researchers at the Solar Energy Research Institute is gratefully acknowledged. David Benson has supported most of the solar pond research, particularly in identifying alternative salts for salt gradient solar ponds. John Webb conducted the measurements of optical properties of salt solutions. Jun Henderson and Cecile Leboeuf developed computer programs to simulate solar pond performance. Ken Brown investigated solar pond applications to industrial process heat.

\subsection{REFERENCES}

Apte, Anand; "Solar Pond Power Plant," PRC Energy Analysis Co. briefing, September 7, 1978.

Battelle Pacific Northwest Laboratories, "The Nonconvecting Solar Pond: An Overview of Technological Status and Possible Application," BNWL-1891, January 1975.

Beard, J. Taylor; Iachetta, F. A. and Lilleleht, L. U. "Annual Collection and Storage of Solar Energy for the Heating of Buildings." University of Virginia, Report No. UVA/532142/MAE78/102, September 1978.

Brown, K. C.; et al. End-Use Matching for Solar Industrial Process Heat. Golden, CO: Solar Energy Research Institute; October 1979.

Casamajor, A. B. and Parsons, R. E. "Design Guide for Shallow Solar Ponds." Lawrence Livermore Laboratory, UCRL-52385 Kev. 1, January 8, 1979.

Cavaleri, G. and Foligno, G. "Proposal for the Production and Seasonal Storage of Hot Water to Heat a City." Snlar Energy, Vol. 19, No. $\dot{6}$ pp. $677-683,1977$.

Dickinson, W. C.; Clark, A. F.; Day, J. A. and Wouters, L. F. "The Shallow Solar Pond Energy Conversion System." Solar Energy, Vol. 18, pp. 3-10, 1976.

Dickinson, W. C.; Brown, K. C. Economic Analysis of Solar Industrial Process Heat Systems. UCRL-52814. Livermore, CA: Lawrence Livermore Laboratory; August 17, 1979.

Edesess, M.; Henderson, J.; Jayadev, T. S. A Simple Design Tool for Sizing Solar Ponds. Golden, CO: Solar Energy Research Institute; SERI/RR-351-347. December 1979.

Escourt, V. F.; et al. "Tests of a Two-Stage Combined Dry Scrubber $/ \mathrm{SO}_{2}$ Absorber Using Sodium or Calcium." Proceedings, 40th Annual Mecting of: the American Power Cónference, Chicago, IL: Apri1 26, 1978. 
Felsvang, K.; (Niro Atomizer Co.). "Results of Pilot Plant Operations for $\mathrm{SE}_{2}$ Absorption." Presentation at the Western Precipitation Seminar at the Tamarron Resort, Durango, CO: May 20-21, 1978.

Groh, John E. "Liquid Foam--Greenhouse Insulation and Shading Techniques." Presented at International Symposium on Controlled-Environment Agriculture, Tucson, Arizona sponsored by Environmental Research Laboratory, University of Arizona, April 7-8, 1977.

Hooker, D. W.; West, R. E. Industrial Process Heat Case Studies. Golden, CO: Solar Energy Research Institute; SERI/TR-34-323. Forthcoming.

Jayadev, T. -S.; Henderson, J. "Salt Concentration fradient Solar Ponds." Modeling and (ntimization Proceedings of 1979 ISES Conference; Atlanta, GA: Hay 28 , 1979 .

Jayadev, T. S.; Henderson, J.; Finegold, J.; Benson, D. Conversion System Overview Assessment, Volume I. Golden, $\mathrm{CO}$ : Solar Energy Research Institute; SERI/TR-35-078; August, 1979.

Leshuk, J. P.; Zaworski, R. J.; Styris, D. L. and Harling, 0. K. "Solar Pond Stability Experiments," Solar Energy, 1978.

Linke, W. F., editor. Solubility of Inorganic and Metal-Organic Compounds, Vol. II. American Chemical Society, 1965.

Margen, Peter "A Central System for Annual Solar Heat." Solar Age, Vol. 3, No. 10, pp. 22-26, Uctöber 1970.

Nielsen, C. E. "Nonconvective Salt Cradient Solar Ponds." Solar Energy Handbook, edited by W. C. nirkinson and P. N. Cheremisinoff, to be published by Marcel vekker, III: , 1979.

Rabl, Ari and Nielsen, Car1 E. "Solar Ponds for Space Heating." Solar Fnergy, Vol. 17, pp. 1-12, 1975.

Ray, M. "Coming: War over Wastes." Electrical World, October 15, 1978:

Rush, R. E. and Edwards, R. A. "Evaluation of Three $20 \mathrm{MW}$ Prototype Flue Gas Desulfurization Processes." EPRI Report FP-713-SY, March 1978.

Sargent, S. L. "An Overview of Solar Pond Technology." Solar Industria1 Process Heat Conference; Oakland, CA: October 31-November 2, 1979.

Saulnier, B.; Savage, S.; Chepurn1y, N. "Experimental Testing of a Solar Pond." Presented at the International Solar Energy Conference in Los Angeles. Brace Institute Report No, R-119, 1975.

Tabor, H. "Solar Ponds: Large Area Collectors for Power Production." Solar Energy 7 (No. 4, 1963): pp. 189-194.

Tabor, H.; Matz, R. "A Status Report on Solar Pond Projects." Solar Energy 9 (No. 4, 1965): Pp. 177-182. 
Taylor, T. B. "Low Cost Solar Energy." International Scientific Forum on an Acceptable Nuclear Energy Future of the World; Fort Lauderdale, FL: November $11,1977$.

Zangrando, F. and Bryant, H. C. "A Salt Gradient Solar Pond." Solar Age 3 (No. 4), April 1978. 


\begin{tabular}{|c|c|c|}
\hline $\begin{array}{l}\text { Document Control } \\
\text { Page }\end{array}$ & $\begin{array}{r}\text { 1. SERI Report No. } \\
\text { TR-731-587 }\end{array}$ & 3. Recipient's Accession No. \\
\hline \multicolumn{2}{|l|}{ 4. Title and Subtitle } & $\begin{array}{r}\text { 5. Publication Date } \\
\text { April } 1980 \\
\end{array}$ \\
\hline \multicolumn{3}{|c|}{. } \\
\hline \multicolumn{2}{|c|}{$\begin{array}{l}\text { 7. Author(s) } \\
\text { T. S. Jayadev, Michael Edesess }\end{array}$} & 8. Periorming Organization Rept. No. \\
\hline \multicolumn{2}{|c|}{$\begin{array}{l}\text { 9. Performing Organization Name and Address } \\
\text { Solar Energy Research Institute } \\
\text { 1617 Cole Boulevard } \\
\text { Golden, Colorado } 80401\end{array}$} & $\begin{array}{l}\text { 10. Project/Task/Work Unit No. } \\
3525.12 \\
\begin{array}{l}\text { 11. Contract (C) or Grant (G) No. } \\
\text { (C) } \\
\text { (G) }\end{array}\end{array}$ \\
\hline \multicolumn{2}{|c|}{ 12. Sponsoring Organization Name and Address } & $\begin{array}{l}\text { 13. Type of Report \& Period Covered } \\
\text { T'erhnical. Report }\end{array}$ \\
\hline \multicolumn{3}{|l|}{ 15. Supplementary Nülés } \\
\hline \multicolumn{3}{|c|}{$\begin{array}{l}\text { 16. Abstract (Limit: } 200 \text { words) } \\
\text { Solar ponds are probably the simplest and least expensive technology for } \\
\text { conversion of solar energy to thermal energy. The solar pond is unique in its } \\
\text { ability to act both as collector and storage. The cost of a solar pond per unit } \\
\text { area is considerably less than that of any active collector available today. The } \\
\text { conbination of their economic and technical factors makes solar ponds attractive } \\
\text { for district heating and industrial process heat applications. Solar ponds have } \\
\text { the potential to displace significant quantities of fossil fuel in low-temperature } \\
\text { heating applications in nonurban areas. }\end{array}$} \\
\hline \multicolumn{3}{|c|}{$\begin{array}{l}\text { a. Descriptors Solar Ponds ; Salt Gradient Solar Pond } \\
\text { Solar Heating i Industrial process Heat : Salts , } \\
\text {; Sodium Sulfates ; Magnesium Chlorides } \\
\text { b. Identifiers/Open-Ended Terms } \\
\\
\text { c. UC Categories } \\
\quad 59\end{array}$} \\
\hline \multicolumn{2}{|c|}{$\begin{array}{l}\text { 18. Availability Statement } \\
\text { National Technical Information Service } \\
\text { U. S. Department of Commerce } \\
\text { 5285 Port Royal Road } \\
\text { Springfield, Virginia } 22161\end{array}$} & $\begin{array}{r}\begin{array}{r}\text { 19. Of Pages } \\
44\end{array} \\
\$ 4.50\end{array}$ \\
\hline
\end{tabular}

